\title{
1 Do Not Disperse the Collection! Motivations and Strategies for Protecting Cuneiform Scholarship in the First Millennium BCE
}

\subsection{Introduction}

By the early first millennium BCE, cuneiform culture was fighting a long, slow battle against obsolescence. Alphabetic scripts from the Levant, comprising just a few dozen characters, were easy to memorise and straightforward to use. By contrast the venerable family of cuneiform scripts had acquired multiple layers of complexity over more than two millennia of use in Babylonia, Assyria, and their spheres of influence. A functionary of the Assyrian Empire in the eighth or seventh centuries BCE minimally needed to master nearly 100 cuneiform signs, with around 35 logographic and over 80 syllabic values, in order to read everyday imperial correspondence. ${ }^{1}$ This was a significant intellectual burden, which even the governor of the Babylonian city of Ur sought to be relieved of, asking Sargon II in c. 800 BCE: "if it is acceptable to the king, let me write and send my messages to the king in Aramaic." 2 The king refused, citing not practical reasons but protocol and his own personal preference: it was "an established regulation" that royal correspondence must be in Akkadian cuneiform. ${ }^{3}$

Anyone with pretensions to learning required perhaps five times or more than that range of reading knowledge, not only in the vernacular Semitic language Akkadian but also in the literary isolate Sumerian, ${ }^{4}$ acquired through years

1 Greta Van Buylaere, "A Palaeographic Analysis of Neo-Assyrian” (PhD diss., University of Udine, 2009).

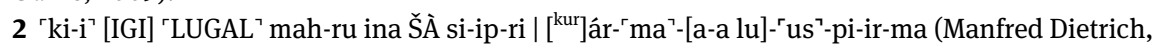
The Neo-Babylonian Correspondence of Sargon and Sennacherib, State Archives of Assyria 17 [Helsinki: Helsinki University Press, 2003], no. 2 obv. 15-16).

3 mi-nam-ma ina ši-pir-ti | ak-ka-da-at-tu la ta-šaț-țar-ma | la tu-šeb-bi-la kit-ta ši-pir-tu | šá ina ŠÀ-bi ta-šaț-ța-ru | ki-i pi-i a-gan-ni-tim-ma i-da-at | lu-ú šak-na-at "Why do you not write and send Akkadian in messages? Truly, the message that you write in it must be according to these conventions. It really is an established regulation." (Dietrich, The Neo-Babylonian Correspondence, no. 2 obv. 16-20).

4 Eleanor Robson and Greta Van Buylaere, “Assyrian-Babylonian Scholarly Literacies” (unpublished manuscript). 
of painstaking copying and rote memorisation, studying under a master scholar. ${ }^{5}$ Even the simplest cuneiform texts were a challenge to read but most people with a reasonable degree of functional literacy would probably also have been able to muddle through a royal inscription or a passage from a narrative literary text such as The Epic of Gilgamesh, as these genres mostly used simple spelling conventions. However, mastering genres such as divination, healing, incantation, and ritual required further specialised learning: not only technical vocabulary but also highly context-specific spellings. ${ }^{6}$

Take for example the simple word šumma, "if." An Assyrian imperial bureaucrat could choose to write this as šum-ma, šúm-ma or possibly šum 4 -ma (where acute and grave accents and subscript numerals are the modern convention for disambiguating homophonous cuneiform signs in alphabetic transliteration). He would have been expected to recognise all three alternatives when reading. ${ }^{7}$ However, a scholar of terrestrial or celestial omens, a healer looking up medical recipes, or a performer of incantations and rituals also had to be conversant with the logographic writings $\mathrm{BE}$ and $\mathrm{U}_{4}$ - which represent the whole word in one short sign - as well as the Sumerian tukum-bi, written with a long sequence comprising the signs ŠU, GAR, TUR, LAL, and BI. ${ }^{8}$ Conversely, in everyday contexts the noun amēlu, "man", was almost invariably written with the simple logogram LÚ. But scholarly genres could in addition substitute it with NA, syllabic spellings such as a-me-lu, $a$-mé-lu, $a-m e_{8}-l u_{4}$ or $\grave{a}-m e_{8}$-lú, or even the elaborate logogram LÚ.U ${ }_{18}$.LU.

In the light of these highly differentiated cuneiform literacies then, what are we to make of the fact that some copyists of scholarly works were apparently obsessed with the thought that others might steal their knowledge? From at least the late second millennium BCE, and regularly from the eighth century BCE onwards, we find injunctions to secrecy, and against loss and theft, on a wide variety of tablets written by a range of different people. ${ }^{9}$ For instance, in 701 BCE

5 Petra D. Gesche, Schulunterricht in Babylonien im ersten Jahrtausend v. Chr., Alter Orient und Altes Testament 275 (Münster: Ugarit, 2000); Eleanor Robson, "The Production and Dissemination of Scholarly Knowledge," in The Oxford Handbook of Cuneiform Culture, ed. Karen Radner and Eleanor Robson (Oxford: Oxford University Press, 2011), 557-76, at 562-69.

6 Niek Veldhuis, "Levels of Literacy," in The Oxford Handbook of Cuneiform Culture, ed. Karen Radner and Eleanor Robson (Oxford: Oxford University Press, 2011), 68-89.

7 Data from the Neo-Assyrian glossary of the State Archives of Assyria online http://oracc.org/ saao/akk-x-neoass, accessed 8 August 2016.

8 Data from the Standard Babylonian and Sumerian glossaries of the Corpus of Ancient Mesopotamian Scholarship http://oracc.org/cams/gkab/akk-x-stdbab and http://oracc.org/cams/gkab/ sux, accessed 8 August 2016.

9 For Middle Babylonian and Middle Assyrian examples see, e.g., Hermann Hunger, Babylonische und Assyrische Kolophone (Kevelaer: Butzon \& Bercker; Neukirchen-Vluyn: Neukirchener, 
in the Assyrian provincial town of Huzirina, apprentice scribe Nabu-rehtu-uṣur copied out the literary comedy now known as The Poor Man of Nippur, enjoining:

Whoever takes away (this tablet), may the god Ea take him away! At the command of the god Nabu, who lives in the Ezida temple, may he have no descendants, no offspring!

Do not take away the tablets! Do not disperse the collection! Taboo of the god Ea, king of the Abyss. ${ }^{10}$

Over half a millennium later, in the southern Babylonian city of Uruk, the young Anu-aba-uter calculated a table of expected lunar eclipses for his father Anubelšunu, a kalû-lamenter. Dating his tablet to the ancient equivalent of April 191 BCE, he admonished:

Whoever fears the gods Anu, Ellil and Ea [shall not take] it away by theft(?). Ephemeris, wisdom of Anu-ship, secret of the [great] gods, treasure of the scholars. The learned may show [the learned]; the unlearned may not [see. Taboo] of Anu, Ellil [and Ea, the great gods]. ${ }^{11}$

Who were these putative thieves, the "unlearned" yet highly cuneiform-literate rogues who would risk the wrath of the gods in order to gain access to such texts? Given the huge amount of time and intellectual labour that the scholars themselves had personally invested in the acquisition of sufficient expertise to comprehend learned writings, they cannot possibly have imagined that a casual reader could make any sense of such a tablet if they had found one dropped in the street. Yet the threat was real enough for genuine concern to be expressed again and again over millennia. This paper attempts to answers the conundrum of the perceived vulnerability of this intrinsically impenetrable knowledge system. ${ }^{12}$

1968), nos. 40, 50; Alan Lenzi, Secrecy and the Gods: Secret Knowledge in Ancient Mesopotamia and Biblical Israel (Helsinki: The Neo-Assyrian Text Corpus Project, 2008), 216-19.

10 ša IR ${ }^{\mathrm{d}} 60$ lit-bal-šú | ina qí-bit ${ }^{\mathrm{d}}$ MUATI a-šib É.ZI.DA | a-a GẤL ${ }^{-s ̌ i}$ NUNUZ-šú na-an-nab-šú țup-pi la 'ta-ta'-bil | ${ }^{\mathrm{im}}$ GÚ.[LÁ] la ta-par-ra-ru | [ik]-'kib` d 60 LUGAL ABZU (Oliver R. Gurney and Jacob J. Finkelstein, The Sultantepe Tablets, Volume I [London: British Institute of Archaeology at Ankara, 1957], no. 38 rev. ii 11-13, 16-18).

11 pa-lih 2150 u 40 ina šur ?'qa ? [la TÙM]-šú | a-ru-ú né-me-qí d 60 -ú-tú rAD.HAL DINGIR.[MEŠ

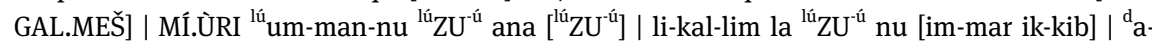
'nù? d EN.LÍL 'ù' ['é-a DINGIR.MEŠ GAL.MEŠ] (Otto Neugebauer, Astronomical Cuneiform Texts, Volumes I-III (Berlin: Springer, 1955), no. 135U rev. 12-16; cf. Kathryn Stevens, "Secrets in the Library: Protected Knowledge and Professional Identity in Late Babylonian Uruk,” Iraq 75 (2013): 211-53, at 252 no. 45.

12 This article arises from the UK AHRC-funded research project The Geography of Knowledge in Assyria and Babylonia (AH/E509258/1), which I ran at the University of Cambridge, 2007-12 (http://oracc .org/cams/gkab). The project website includes online editions of the scholarly 


\subsection{Old and New Approaches to the Topic}

Assyriologists have sought for a long time to identify the textual features and genres of cuneiform scholarship that attracted protective formulae. For much of the twentieth century, the study of Mesopotamian intellectual history was tightly focused on the production of text editions in order to (re)construct the textual evidence base. It was therefore natural to assume that ancient motivations for protecting works of cuneiform scholarship lay in the texts themselves: that they represented a body of Geheimwissen, "secret knowledge", that had to be divinely protected from outsiders at all costs. Concluding an extensive survey of earlier work in the field, as part of his own investigations into the phenomenon, Alan Lenzi admitted defeat. ${ }^{13}$ It was "a dead-end," he argued, to even ask why particular compositions or textual genres were marked as secret knowledge, as this label was "applied inconsistently" to works of cuneiform scholarship. One amongst many otherwise identical manuscripts of a particular composition might invoke divine protection, though the others do not. One chapter of a scholarly work might be marked as "secret," the others not. The very parameters of cuneiform esotericism were apparently so esoteric as to be utterly inscrutable, even to the modern ranks of the "learned."

More recently, Kathryn Stevens persuasively demonstrated that earlier generations of historians have been missing a trick. ${ }^{14}$ Rather than treating Geheimwissen as a property of the texts themselves, we should see the secrecy label as just one of several types of protective strategies. Such formulations, she argues, were an expression of "clearly articulated relationships between the professional specialism(s) of the individual scholar and the texts he sought to protect." ${ }^{15}$ Her case study was the small, close-knit intellectual community of the Babylonian city of Uruk in the fifth to third centuries BCE, where Anu-aba-uter and Anu-belšunu lived and worked. Their circle comprised men from just three or four extended families, each named after an eponymous ancestor, and each specialising in one or two venerable scholarly professions.

Descendants of Sin-leqe-unninni, such as Anu-belšunu, called themselves kalûs, "lamenters," specialists in soothing the hearts of angered gods though prayer, ritual and lamentation. Members of the Šangu-Ninurta, Ekur-zakir and Hunzu clans self-identified as āšipus, often translated rather awkwardly into

tablets from Huzirina, Kalhu and Uruk discussed here. I am most grateful to Kathryn Stevens for her constructive and perspicacious comments on the final draft.

13 Lenzi, Secrecy and the Gods, 214.

14 Stevens, "Secrets in the Library."

15 Stevens, "Secrets in the Library," 231. 
English as "exorcist" or "incantation-priest" but whose main role was to heal their clients through physical therapy or ritual reconciliation with the divine. A few of the more numerate men in each family also trained as țpšar Enūma Anu Ellil, literally "scribes of the celestial omen series 'When the gods Anu and Ellil,"” usually rendered as “astrologer,” By this late period, short-term divination through observing the moon and planets was obsolete, as the precise movements of the major heavenly bodies could be determined mathematically. Instead the Hellenistic țup̌ar Enūma Anu Ellil developed increasingly sophisticated methods for predicting lunar and planetary motion, testing them against night-time observations. They also drew up horoscopes for private clientele. Each generation taught members of the next, usually sons and nephews, but also youngsters of the other families, as well as members of the elite Ahu'tu clan, which produced several of Uruk's city governors. All of these men, and many other members of their extended families, also drew income and social status from prebends, or rights to temple income, in return for a few days of ritual duty a year. ${ }^{16}$

Stevens showed that in Late Babylonian Uruk each composer or copyist of cuneiform scholarship chose whether or not to invoke protective formulae in the colophons of the texts they wrote. ${ }^{17}$ Men with the title $\bar{a}$ šipu or kalû were most likely to protect works most closely associated with their respective professional specialisms but not to bother protecting those that were intellectually interesting but not closely tied to personal professional identity. This was not a hard and fast rule, but clear trends were visible. In the temple the primary duty of kalûs such as Anu-belšunu, for instance, was to soothe and sympathise with the gods in their times of distress - one of those times being during a lunar eclipse. Knowing precisely when such eclipses would occur enabled them to perform their lamentation rituals with ultimate efficacy. Eclipse tables were thus at the intellectual heart of the kalûs' cultic role, overseen by the sky-god Anu with the great gods Ellil and Ea on either side of him. It made complete sense for young Anu-aba-uter to invoke their protection as he calculated potential times of divine upset.

Yet even Stevens's major breakthrough does not give a complete answer. It does not explain why some individuals and communities did not invoke secrecy

16 On the principles of Babylonian prebendary priesthood see Caroline Waerzeggers, "The Babylonian Priesthood in the Long Sixth Century BC," Bulletin of the Institute of Classical Studies 54 (2011): 59-70. The literature on cuneiform scholarship in Late Babylonian Uruk is extensive; see, with many further references, most recently Eleanor Robson "The Socio-economics of Cuneiform Scholarship after the 'End of Archives': Views from Borsippa and Uruk," in At the Dawn of History: Ancient Near Eastern Studies in Honour of J. N. Postgate, ed. Yagmur Heffron, Adam Stone, and Martin Worthington (Winona Lake: Eisenbrauns, 2017), 455-70.

17 Stevens, "Secrets in the Library." 
clauses or protective formulae even on their most precious scholarship, and nor does it address the question of who the supposed perpetrators might have been. In what follows I take Stevens's model as a starting point to consider which scholarly groups felt their written knowledge to be most and least at risk, and from whom. I shall also draw on recent work on the social geographies of cuneiform scholarship, as the spread and status of high cuneiform culture diminished over the course of the first millennium BCE. ${ }^{18}$

As I shall argue here, the overarching threat was not from below, via the widespread adoption of alphabetic literacy, but rather from above. In the midfirst millennium cuneiform scholarship underwent two major "survival bottlenecks," to borrow a phrase from conservation biology: near-catastrophic events that threaten a population's survival, through significantly reducing its size and diversity. The first of those began with Assyrian king Ashurbnanipal's large scale appropriation of cuneiform scholarship, peaking after the civil war against his brother Šamaš-šumu-ukin in 648 BCE and culminating in the collapse of the Assyrian Empire three decades later. The second comprised a systemic attack on Babylonian temple communities as sources of political dissent and rebellion, instigated by the Achaemenid king Darius in 521 BCE and culminating in a thorough purge by his son Xerxes II in 484 BCE. Although cuneiform scholarship survived both bottlenecks, it was badly compromised each time, and had to adapt to significantly less favourable circumstances thereafter. The motivations and strategies employed for protecting learned writings can only be fully understood, I argue, in this wider political context.

The rest of this paper is thus in three parts. I shall begin by considering four communities of textual production in eighth and seventh-century Assyria, which each shared and protected their knowledge to different degrees. In the middle section I expand on the Assyrian and Achaemenid royal actions that resulted in survival bottlenecks for cuneiform scholarship and consider their long-term repercussions. In

18 Eleanor Robson, "Empirical Scholarship in the Neo-Assyrian Court," in The Empirical Dimension of Ancient Near Eastern Studies, ed. Gebhardt Selz and Klaus Wagensonner (Vienna: LIT, 2011), 603-30; eadem, "Reading the Libraries of Assyria and Babylonia," in Ancient Libraries, ed. Jason König, Katerina Oikonomopoulos, and Greg Woolf (Cambridge: Cambridge University Press, 2013), 38-56; eadem, "Tracing Networks of Cuneiform Scholarship with Oracc, GKAB and Google Earth," in Archaeologies of Text: Archaeology, Technology and Ethics, ed. Matthew Rutz and Morag Kersel (Oxford: Oxbow Books, 2014), 142-63; eadem, "The Socio-economics of Cuneiform Scholarship”; eadem, Ancient Knowledge Networks: A Social Geography of Cuneiform Scholarship in the First Millennium BC (forthcoming); Eleanor Robson and Kathryn Stevens, "Scholarly Tablet Collections in First-Millennium Assyria and Babylonia," in The Earliest Libraries: Library Tradition in the Ancient Near East, ed. Gojko Barjamovic and Kim Ryholt (Oxford: Oxford University Press, forthcoming). 
the final part before the conclusion I look at the strategies of secrecy versus sharing in Late Babylonian contexts. I revisit Stevens' work on late Achaemenid and Hellenistic Uruk, situating it in this wider context. Lastly I come to the very end of the cuneiform tradition in c. 100 BCE. As the very last known practitioners of their disciplines, what motivations did the scholars of Parthian Babylon have to share and protect scholarly knowledge that was widely considered obsolete?

\subsection{Sharing and Protecting Scholarship in the Assyrian Empire}

Two seventh-century scholarly communities exhibit the classic model of sharing and protecting knowledge in cuneiform culture, around a so-called "distributed library." 19 In the ancient city of Assur, cultural heart of the Assyrian empire and close to the seat of power, the Baba-šumu-ibni family worked as āšipu-healers, affiliated to the god Aššur's temple Ešarra. When Assur fell to the invading Medes and Babylonians in 614 BCE, the family left behind some 600 scholarly tablets in their city-centre house, about of a quarter of which have colophons showing that they were written over four generations by their own family members and at least thirteen unrelated apprentices. ${ }^{20}$ Nearly three-quarters of their writings relate somehow to their profession: medical recipes, rituals and incantations; but they also include temple ceremonies, hymns and prayers, and a small collection of bilingual "lexical lists" which explicated the complexities of cuneiform script and the subtle relationships between Sumerian and Akkadian vocabulary. ${ }^{21}$ Meanwhile, some $430 \mathrm{~km}$ to the northwest in the politically important province of Harran, several generations of the Nur-Šamaš family of šangh-priests ran a scribal school for the sons of mid-ranking imperial officials. ${ }^{22}$ It operated in the

19 Robson and Stevens, "Scholarly Tablet Collections in First-Millennium Assyria and Babylonia."

20 Stefan M. Maul, "Die Tontafelbibliothek aus dem sogenannten »Haus des Beschwörungspriesters, " Assur-Forschungen: Arbeiten aus der Forschungsstelle »Edition Literarische Keilschrifttexte aus Assur der Heidelberger Akademie der Wissenschaften, ed. Stefan M. Maul and Nils P. Heeßel (Wiesbaden: Harrassowitz, 2010), 189-228.

21 The research project Edition literarischer Texte aus Assur, led by Professor Stefan Maul at the University of Heidelberg, is systematically publishing the scholarly texts from this house and elsewhere in Assur (http://www.haw.uni-heidelberg.de/forschung/forschungsstellen/ keilschrift/index.de.html, accessed 9 September 2016).

22 Robson, "Tracing Networks of Cuneiform Scholarship," 152-53. The Huzirina tablets were published in scale drawings by Gurney and Finkelstein, The Sultantepe Tablets; Oliver R. Gurney 
small town of Huzirina for at least a hundred years, until it too was abandoned at the very end of empire in the late seventh century BCE. When the last occupants left the building they carefully hid away nearly 400 tablets in the hope that they would one day return for them. This collection includes a similar proportion of incantations and rituals to that of the Assur āšipus, but a smaller quantity of medical recipes and a relatively larger number of hymns, omen collections and literary works. About sixty of the tablets have surviving colophons, written by the Nur-Šamaš men and at least twenty different "apprentices,” šamallû.

Although hundreds of kilometres apart and serving very different scholarly communities - professional urban healers, imperial administrators aspiring to a cultured education - these two families shared a common attitude to knowledge and who could access it. On the one hand they protected their tablets against theft and loss, but they also made copies for others to read. For instance, Nabu-rehtu-uṣur's colophon to The Poor Man of Nippur, already quoted above, says in full:

Written and checked [(from an original)]. [Handiwork of] Nabu-rehtu-uṣur, scribal apprentice, pupil of Nabu-ahu-iddina, eunuch, for the viewing of Qurdi-Nergal.

Whoever takes away (this tablet), may Ea take him away! At the command of Nabu, who lives in Ezida, may he have no descendants, no offspring.

In the month Addaru (Month XII), on the 21st day, eponymate of Hanani, the provincial governor of Til-Barsip (701 BCE).

Do not take away the tablets! Do not disperse the collection! Taboo of the god Ea, king of the Abyss. $^{23}$

Likewise, one of the Assur āšipus writes the following at the end of a ritual to dispel the evil of a dog which has misbehaved in his client's house:

Written and checked according to the wording of its original. Tablet of Nabu-bessunu, āšipu of Aššur's temple, son of Baba-šumu-ibni the chief āšipu of the Ešarra temple.

Whoever takes away this tablet, may the god Šamaš take away his eyes! ${ }^{24}$

and and Peter Hulin, The Sultantepe Tablets, Volume II (London: British Institute of Archaeology at Ankara, 1964). For an up-to-date catalogue, bibliography and online edition see http://oracc. org/cams/gkab.

23 ša IR ${ }^{\mathrm{d}} 60$ lit-bal-šú | ina qí-bit ${ }^{\mathrm{d}}$ MUATI a-šib É.ZI.DA | a-a GÁL ${ }^{-s i}$ NUNUZ-šú na-an-nab-šú țup-pi la 'ta-ta'-bil | ${ }^{\mathrm{im}} \mathrm{GÚ}$.[LÁ] la ta-par-ra-ru | [ik]- 'kib' ${ }^{\text {d }} 60$ LUGAL ABZU (Gurney and Finkelstein, The Sultantepe Tablets, no. 38 rev. ii 11-13, 16-18).

24 ina KA SUMUN.BI SAR 'IGI.KÂR' | IM ${ }^{\mathrm{md}} \mathrm{UMBISAG}_{2}$-be-su-'nu' ${ }^{-}$lú MAŠ.MAŠ É ${ }^{\mathrm{d}}$ [aš-šur] | PEŠ

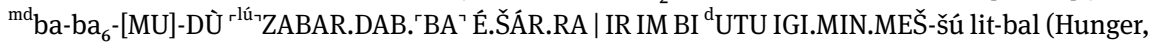
Babylonische und Assyrische Kolophone, no. 193 rev. 22-27; Stefan M. Maul, Zukunftsbewältigung: 
Colophons such as these reveal, first, that tablets were copied from other manuscripts, which must have moved from place to place and from person to person in order for this to happen. In the examples quoted above, the details of the original are lost or considered unimportant, but both collections include copies made from manuscripts from Babylon and from the goddess Gula's temple in Assur. There are also manuscripts originating from Nineveh and Uruk amongst the Assur āšipus's tablets. ${ }^{25}$ It was perhaps good manners to acknowledge one's sources, especially if copying from an individual or institution; and it also helped to keep track of the origins of variant recensions; but it could also be a matter of prestige to have access to material from glamorous, far-away cities or powerful temples.

Second, tablets could be produced precisely in order for others to read them. In Huzirina the recipient was most often Qurdi-Nergal of the Nur-Šamaš family, as in the example above, but tablets could also be intended for more than one person $^{26}$ :

Writer: Nabu-ețiranni. In Kislimu (Month IX), on the 26th day, eponymate of Nergal-šarru-uṣur, chief cupbearer (678 BCE).

For the viewing of Bel-ah-iddin, the šangu-priest; [for the viewing of ...]-Ninurta; [for] the viewing of [...]-...-ușur, the novice; for the viewing of Rimut-ilani, the junior asû-healer; for the viewing of Zer-ukin, the junior scribal apprentice: it has been quickly excerpted for their viewing. ${ }^{27}$

Eine Untersuchung altorientalischen Denkens anhand der babylonisch-assyrischen Löserituale (Namburbi) (Mainz: von Zabern, 1994), 12-23; idem, “Die Tontafelbibliothek,” 195).

25 Babylonian originals at Huzirina: Gurney and Hulin, The Sultantepe Tablets, nos. 136, 232, 323; at Assur: Hunger, Babylonische und Assyrische Kolophone, no. 203I; manuscripts from Gula's temple in Assur at Huzirina: Gurney and Finkelstein, The Sultantepe Tablets, no. 73; at Assur: Hunger, Babylonische und Assyrische Kolophone, nos. 199D, 202A, 203K; from Nineveh and from Uruk at Assur: Hunger, Babylonische und Assyrische Kolophone, nos. 203B, 211, 212A.

26 Other tablets for Qurdi-Nergal's viewing: Gurney and Hulin, The Sultantepe Tablets, nos. 161, 172.

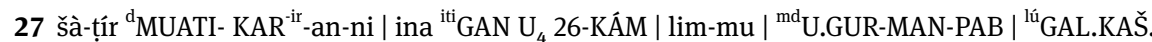

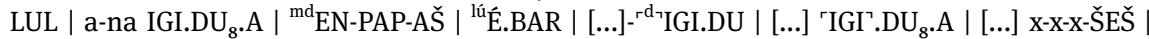

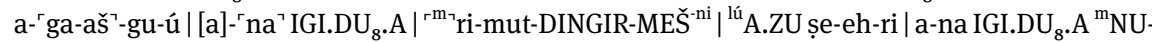

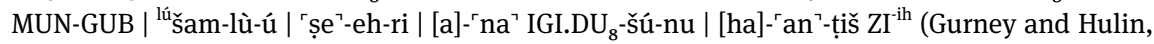
The Sultantepe Tablets, no. 301 rev. ii 11'-iii 12'; Alasdair Livingstone, “On the Organized Release of Doves to Secure Compliance of a Higher Authority," in Wisdom, Gods and Literature: Studies in Assyriology in Honour of W.G. Lambert, ed. Andrew R. George and Irving L. Finkel [Winona Lake: Eisenbrauns, 2000], 375-88: source GG). 
Amongst the Assur āšipus, however it was much more usual to "quickly excerpt in order to grasp what to do," ana șabāt epēši hanțiš nasāhu. ${ }^{28}$ As Stefan Maul pointed out in his discussion of the Baba-šumu-ibni family, the phrase hanțiš (or zamar) nasha, "quickly excerpted," indicates that the copy was made under time pressure for use in therapeutic practice, presumably from an original that had been borrowed and needed to be returned, or which had been copied in situ elsewhere. ${ }^{29}$

In other words, tablets did circulate, sometimes over long distances - it was a journey of well over $700 \mathrm{~km}$ upriver from Babylon to Huzirina, for instance but under closely prescribed circumstances. Given that tablets could and should move around, it was important to regulate those movements, whether by naming the intended recipients individually, or by warning borrowers not to become thieves. Written knowledge was a scarce and precious commodity: sharing what one had, within socially acceptable parameters, was an important means of enabling access to more, owned by others. Protection clauses reminded members of the group of the social contract entailed in borrowing and copying, and the professional ostracism at stake should it be transgressed.

These markers of the "distributed library," as Robson and Stevens term it, whereby professional and scholarly knowledge circulates within a self-policing community, in both text and in memory, are not restricted to seventh-century Assyria; as we argue in that paper, they are also attested amongst the āšipus and kalûs of Late Babylonian Uruk discussed briefly above. ${ }^{30}$ However, they are not universally attested, even in seventh-century Assyria. By turning our attention to communities which did not protect their writings with written admonitions, we will get a clearer sense of what this practice meant.

The Issaran-šumu-ukin and Gabbu-ilani-ereš families had produced advisors to Assyrian monarchs since at least the early ninth century BCE, when the main royal residence moved to Kalhu, some $70 \mathrm{~km}$ up the river Tigris from Assur. The two scholarly families made their devotional base the newly founded Ezida, temple of Nabu, god of wisdom, on the royal citadel. Here they built up a collection of scholarly writings, stored in a dedicated room immediately opposite Nabu's inner shine. When invaders sacked the Ezida temple in 612 BCE, at least 250 tablets

28 E.g., a-na șa-bat e-pe-ši ha-an-țiš na-as-ha (Hunger, Babylonische und Assyrische Kolophone, no. 197A-E; 198A-C).

29 Maul, "Die Tontafelbibliothek," 212-13; Gurney and Finkelstein, The Sultantepe Tablets, nos. 4, 57 are also said to be "quickly excerpted."

30 Robson and Stevens, "Scholarly Tablet Collections in First-Millennium Assyria and Babylonia." 
were still in situ, including around 30 with colophons on them..$^{31}$ They name men from several generations of the two families - although never both together - but there is very little evidence for training of apprentices, as in Huzirina and Assur. ${ }^{32}$ As befitted royal advisors and healers, about a quarter of the families' collection comprised omens for divining the gods' intentions for the land and a further quarter consisted of medical recipes, incantations and rituals. There were also significant numbers of hymns and prayers, lexical texts, and royal inscriptions. A further 85 or more scholarly tablets that had formerly belonged to Gabbu-ilaniereš men also made their way into the royal palace collections in Nineveh - a fact that we shall return to, and account for, in the following section. ${ }^{33}$

Issaran-šumu-ukin's successors fell out of royal favour in the eighth century but the descendants of Gabbu-ilani-ereš continued to serve at court until at least 650 BCE, as royal āšipus, țupšar Enūma Anu Ellil and even as senior scholar, ummânu or rab țupšarrī (literally "expert" or "chief scribe"; the two titles are synonymous). By this time the king was mostly resident in Nineveh, some $35 \mathrm{~km}$ upstream from Kalhu. The palace archives include about 1500 scholarly letters and reports to kings Esarhaddon and Ashurbanipal, some ten percent of which are from Gabbu-ilani-ereš men. They advise the king on state affairs through divination, look after the royal family's health, and take care of royal ritual. But the scholars were not always by his side, as chief āšipu Adad-šumu-uṣur explains to Esarhaddon in about 670 BCE:

Concerning what the king, my lord, wrote to me: “Why haven’t you sent an answer to (my) letter?" - I had to drive to the palace those rams that the chief cook had brought out for

31 The tablets from Ezida were published as scale drawings by Donald J. Wiseman and Jeremy A. Black, Literary Texts from the Temple of Nabû, Cuneiform Texts from Nimrud 4 (London: British School of Archaeology in Iraq, 1996), up-to-date bibliography, catalogue and online edition at http://oracc.org/cams/gkab; recent studies by Robson, "Reading the Libraries," 45-48; eadem, "Tracing Networks of Cuneiform Scholarship," 148-51.

32 A "junior scribal apprentice,” ŠAMAN ${ }_{2}$.LÁ TUR is mentioned on Wiseman and Black, Literary Texts, no. 27 rev. ii 9', on which see further below with note ; and a [...] șeh-ru, "junior [...]," on Wiseman and Black, Literary Texts, no. 220 rev. ii 4', a manuscript of the synonym list Malku= Šarru.

33 For the tablets of Nabu-zuqup-kena see Stephen Lieberman, "A Mesopotamian Background for the So-called Aggadic 'Measures' of Biblical Hermeneutics?” Hebrew Union College Annual 58 (1987): 157-225, at 204 n. 222; Eckart Frahm, “Nabu-zuqup-kenu, das Gilgameš-Epos und der Tod Sargons II," Journal of Cuneiform Studies 51 (1999): 73-90, at 88; for those of his descendants see Simo Parpola, Letters from Assyrian Scholars to the Kings Esarhaddon and Assurbanipal, Part II: Commentary and Appendices (Kevelaer: Butzon \& Bercker, 1983; repr., Winona Lake: Eisenbrauns, 2007), 450-53. 
me, and the writing-board was at my house. Now then, I can look at the writing-board and extract the relevant interpretation. Concerning the ritual against earthquake [...]. ${ }^{34}$

As wealthy and influential courtiers, Adad-šumu-uṣur and his relatives doubtless had homes in Nineveh, but this letter suggests that not all of their scholarly collection was close to hand. It is highly likely that the Gabbu-ilani-ereš family base remained in Kalhu, along with their tablets in the temple there.

The royal scholars of Kalhu, whether descendants of Issaran-šumu-ukin or Gabbu-ilani ereš, display a very different attitude to the protection and sharing of knowledge than their less powerful contemporaries in Assur and Huzirina. They regularly acknowledge that their manuscripts are copies of earlier exemplars but never announce that materials have been "quickly excerpted" from them and never acknowledge the identity of the scribe making the copy for them. ${ }^{35}$ If they borrow tablets from others, there is apparently no hurry to return them. Nor do they appear to countenance sharing or lending. Just once does Nabu-zuqup-kena describe a work as "a secret of the sages" which "the unlearned may not see." 36 The only people that are said to "view" tablets are the owners themselves or their sons. In 711 BCE, for instance, Nabu-zuqup-kena had at least four tablets of divination made for him, all of which end with the comment:

34 ša LUGAL be-lí | iš-pur-an-ni ma-a a-ta-a | GABA.RI e-gír-ti la taš-pur-ra | ina ŠÀ É.GAL a-na

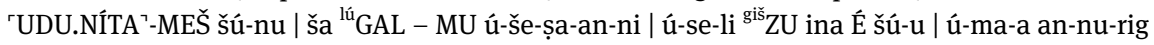
giš ZU | a-mar pi-šìr-šu a-na-sa-ha | ina UGU dul-li ša ri-i-bi (Simo Parpola, Letters from Assyrian and Babylonian Scholars, State Archives of Assyria 10 [Helsinki: Helsinki University Press, 1993], no. 202 obv. 5-13).

35 A detailed analysis by Lieberman, "A Mesopotamian Background," 209-10 showed that Nabu-zuqup-kenu of the Gabbu-ilani-ereš family employed several different copyists.

36 ni-șir-ti NUN.ME là mu-du-ú là IGI ${ }^{-m a r}$ (K 170 + Rm 520 rev 9', an extract from the scholarly commentary Inam gišhurankia, ed. Alasdair Livingstone, Mystical and Mythological Explanatory Works of Assyrian and Babylonian Scholars [Oxford: Clarendon, 1986], 30-33; cf. Lenzi, Secrecy and the Gods, 174). Even if Hunger, Babylonische und Assyrische Kolophone, no. 311 and Lieberman, “A Mesopotamian Background," 205 n. 220 are right to assign the anomalous fragment K 11867 to Nabu-zuqup-kena, the phrase on the colophon of that tablet which Hun-

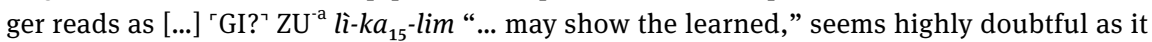
depends on the otherwise unattested reading $\mathrm{ka}_{15}$ for the sign GAR and does not account for the damaged sign at the beginning of the phrase, whose traces do not fit the expected writing $\mathrm{ZU}^{-u}$ for $m \bar{u} d \hat{u}$, "learned." In my opinion, it is more likely to be read as [...] he-"pa'-a lì-šálim, "may he restore the breaks" (cf. the exact parallel phrase in RIMB 2.02.08.05 discussed below in note 39). 
According to the words of an old wooden writing-board of Amel-Uraš-liya(?), son of Esangila-zeru-iddin the diviner. Nabu-zuqup-kena, son of Marduk-šumu-iqiša, descendant of Gabbu-ilani-ereš the chief scribe, had it written and checked it for his (own) viewing. ${ }^{37}$

The only surviving admonitions to future readers relate not to careful treatment of the tablet but to consideration of the quality of the copy. In 684 BCE Nabuzuqup-kena, now an old man, explains that he produced a copy of the scholarly commentary Inam gišhurankia:

For the viewing of Ištar-šumu-ereš my (grand)son. 11/2 years ago my vision deteriorated but I hurriedly bestirred and wrote it. The viewer should not disparage (my efforts). ${ }^{38}$

Similarly, another of Nabu-zuqup-kena's grandsons, Urad-Gula, explains the origins of an old dedicatory inscription he has copied:

Written and checked according to its original. Written according to the wording of damaged tablets. Anyone who views (it) should not disparage (my efforts). (Instead), let him restore the break(s)! ${ }^{39}$

In other words, these men are concerned more with protecting their scholarly reputations than with safeguarding the contents of their writings.

Only three tablets from the collection in the Ezida have (the remains of) divine protection formulae on them: one written by a junior scribe whose name no longer survives ${ }^{40}$ and two by an $\bar{a}$ šipu-healer named Banunu:

37 E.g., ki-i pi-i ${ }^{\text {giš }}$ le-u $u_{5}$-um LIBIR.RA ša ${ }^{\mathrm{m}}$ LÚ- ${ }^{\mathrm{d}} U R A S \check{S}-l i-i a$ DUMU ${ }^{\mathrm{m}}$ É.SAG.ÍL-MU ${ }^{\text {lú HAL }}{ }^{\mathrm{md}} \mathrm{NÀ}-z u-$

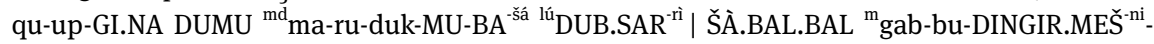

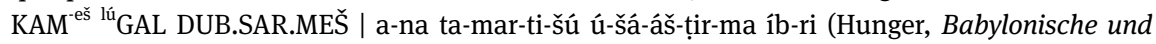
Assyrische Kolophone, no. 297A; cf. Lieberman, “A Mesopotamian Background,” 210).

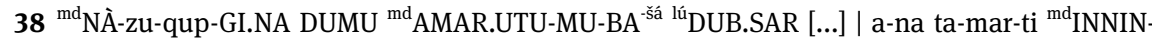
MU-KAM ${ }^{\text {-š }}$ DUMU-ia ul-tu 1 1/2 MU.AN.NA.MEŠ di-ig-la ú-kab-bir-ma za-mar ú-ba-ah-hi-iš-ma ab-r[i? ...] | a-mi-ru la i-ța-ap-pil (Hunger, Babylonische und Assyrische Kolophone, no. 299, ed. Livingstone, Mystical and Mythological Explanatory Works, 29; cf. Lieberman, "A Mesopotamian Background," 213-14).

39 LIBIR.RA.BI.GIM AB.SAR BA.AN.È | i-na KA țup-pi GAZ.MEŠ šà-ṭir a-me-ru la i-ța-pil he-pa-a

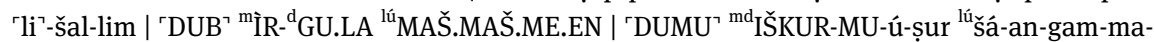
${ }^{\ulcorner} h u^{\urcorner}$ša $^{r m}{ }^{r m}$ AN.ŠÁR-PAP-AŠ` MAN 'KUR' aš-šur ${ }^{\text {ki }}$ (Hunger, Babylonische und Assyrische Kolophone, no. 498 12-17; Grant Frame, Rulers of Babylonia: From the Second Dynasty of Isin to the End of Assyrian Domination (1157-612 BC), Royal Inscriptions of Mesopotamia: Babylonian Periods 2 [Toronto: University of Toronto Press, 1995], no. 2.02.08.05, ex. 01; Parpola, Letters from Assyrian Scholars, 453 no. 15).

40 On a tablet of the astronomical compilation Mul-Apin: [...] 'GIM ' SUMUN-šú SAR-ma bà-rì DUB [...] | [...] ŠAMAN ${ }_{2}$.LÁ TUR ša IR ${ }^{\mathrm{d}}$ UTU [...] | 'ina' dan-na-'ni e-kim-šu' "Written and checked 
Written and checked according to its original. Tablet of Banunu, āšipu. Do not deliberately(?) remove (it). Do not disperse the collection. Taboo of the god Ea, king of the Abyss. ${ }^{41}$

Banunu is also known as the copyist of three further scholarly tablets found in Ezida, but never gives a father's name or any family affiliation. ${ }^{42}$ Was he perhaps a eunuch? Although he may sometimes have worked at court, ${ }^{43}$ he did not have the status or genealogy of the Issaran-šumu-ukin or Gabbu-ilani-ereš men, and may have thus felt the need for divine protection more keenly than they did. Nevertheless, like the Gabbu-ilani-ereš men he did not feel the need to credit his copyists. ${ }^{44}$

There was just one man in seventh-century Assyria who felt more confident than the royal scholars in the security of his tablets, and even less need to share them. Since at least the time of Sargon II (r. 721-705 BCE) kings had collected tablets for the palace, but his great grandson Ashurbanipal (r. 668-c.630 BCE) took that tradition to its logical extreme. ${ }^{45}$ Neither he nor his father Esarhaddon had been first in line for the throne, and thus Ashurbanipal grew up in train-

like its original. Tablet of [...], junior apprentice scribe. Whoever takes it away, may Šamaš [...] remove him by force" (Wiseman and Black, Literary Texts, no. 27 rev. ii 8'-10').

41 On a tablet of the induction ritual for a cult statue, Mīs Pî: 'LIBIR.RA'.BI.GIM AB.SAR.ÀM-ma

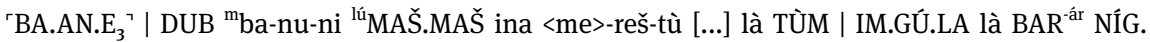
'GIG' dé-a LUGAL ABZU (Wiseman and Black, Literary Texts, no. 170 (+) 188 rev. ii 5'-7') ed. Daisuke Shibata, "A Nimrud Manuscript of the Fourth Tablet of the Series Mis pî, CTN IV 170(+)188, and a Kiutu Incantation to the Sun God," Iraq 70 [2008]: 189-203; cf. Wiseman and Black, Literary Texts, no. 116, a collection of medical recipes and incantations against wounds, ed. Markham J. Geller, "Fragments of Magic, Medicine and Mythology from Nimrud," Bulletin of the School of Oriental and African Studies 63 [2000]: 331-39, at 336-339).

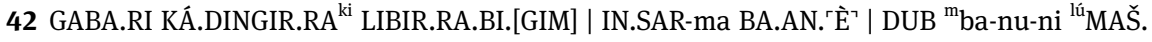
MAŠ "Manuscript of Babylon. Written and checked [like] its original. Tablet of Banunu, āšipu"; 'DUB' mba-nu-ni lú MAŠ.MAŠ “Tablet of Banunu, āšipu” (Wiseman and Black, Literary Texts, no. $61+62$ rev. iii 5'-7'; no. 63 rev iii 28): Tablet 7 and 9 of a series of prayers to Šamaš, god of divination, ed. Wilfred G. Lambert, Babylonian Oracle Questions (Winona Lake: Eisenbrauns, 2007);

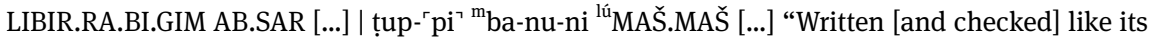
original. Tablet of Banunu, āšipu” (Wiseman and Black, Literary Texts, no. 192 rev. ii 6"-7”), the plant list Uruanna.

43 See F. Mario Fales and J. Nicholas Postgate, Imperial Administrative Records, Part II: Provincial and Military Administration, State Archives of Assyria 11 (Helsinki: Helsinki University Press, 1995), no. 156, to which we will return shortly.

44 Wiseman and Black, Literary Texts, 15.

45 For instance, the cuneiform inscription on a cover of a writing-board found at Kalhu reads,

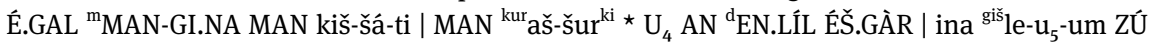

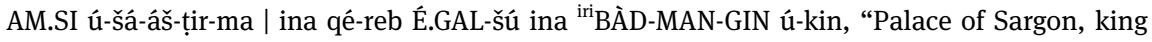
of the world, king of Assyria. He had the series Enūma Anu Ellil written on a writing-board of elephant-ivory and deposited it in his palace at Dur-Šarruken" (ND 3557; Donald J. Wiseman, “Assyrian Writing Boards," Iraq 17 [1955]: 3-13, at 7). 
ing for the priesthood not for kingship..$^{46}$ Ashurbanipal's literacy and fascination with cuneiform scholarship has been extensively studied and discussed. ${ }^{47} \mathrm{He}$ also made use of his knowledge in the practice of kingship, insisting that diviners send him their observations so that he could check their interpretations and advice against the written tradition. ${ }^{48}$ There is no doubt that, building on already substantial royal collections, he amassed a vast "library" of tablets and writing boards for his own private use, especially focused on divination, the extant remains of which comprise around 27,000 tablets and fragments now held in the British Museum. ${ }^{49}$

As the royal citadel of Nineveh was dug primarily by the first generations of Victorian explorers, long before the advent of stratigraphic archaeology, it is now almost impossible to reconstruct exactly what was found where..$^{50}$ In broad outline, however, scholarly tablets were kept in at least two palaces and one or more temples on the citadel, all of which were ransacked during the final destruction of Nineveh in 612 BCE. This means that even if the find contexts had been recorded to current standards, they would show only the tablets' final resting places after the looting, not their normal storage arrangements.

Nevertheless, the tablets themselves shed a good deal of light on the circumstances of their production and intended use. Let us start with the colophons that Ashurbanipal had inscribed on "almost every tablet of importance in the ... collection. ${ }^{51}$ Stephen Lieberman divides them into three broad categories. ${ }^{52}$

46 Alasdair Livingstone, “Ashurbanipal: Literate or Not?” Zeitschrift für Assyriologie 97 (2007): 98-118, at 99.

47 E.g., Pierre Villard, "L’education d'Assurbanipal,” Ktema 22 (1997): 135-49; Livingstone, "Ashurbanipal”; Eckart Frahm, "Keeping Company with Men of Learning: The King as Scholar," in The Oxford Handbook of Cuneiform Culture, ed. Karen Radner and Eleanor Robson (Oxford: Oxford University Press, 2011), 508-33.

48 Robson, "The Production and Dissemination."

49 In addition to some 5000 letters and legal documents, now published in the State Archive of Assyria series and at http://oracc.org/saao/. Data from The British Museum's Ashurbanipal Library Project, headed by Jonathan Taylor, http://oracc.org/asbp/corpus/, accessed 10 August 2016. For a convenient recent overview, with references to further literature, see Robson, "Reading the Libraries," 41-45.

50 Julian E. Reade, "Ninive (Nineveh)," in Reallexikon der Assyriologie und Vorderasiatischen Archäologie, Vol. 9, ed. Dietz O. Edzard (Berlin: De Gruyter, 2001), 388-433, at 421-27.

51 Carl Bezold, Catalogue of the Cuneiform Tablets in the Kouyunjik Collection of the British Museum, Volume 5 (London: The British Museum, 1899), xiii.

52 Stephen Lieberman, "Canonical and Official Cuneiform Texts: Towards an Understanding of Assurbanipal's Personal Tablet Collection," in Lingering over Words: Studies in Ancient Near Eastern Literature in Honor of William L. Moran, ed. Tzvi Abusch, John Huehnergard, and Piotr Steinkeller (Atlanta: Scholars Press, 1990), 305-36. 
First, there are a few surviving witnesses to Ashurbanipal's early career, which end in the "prince" (rūbû) making elaborate prayerful dedications to Nabu, god of wisdom, for deposit in his temple on the Nineveh citadel. ${ }^{53}$ These are likely to have been written by Ashurbanipal himself. Second, the large majority of scholarly tablets, produced by chancery scribes, are stamped, inscribed or painted with a simple property mark, "Palace of Ashurbanipal, king of the world, king of the land of Ashur." 54 Third, a smaller number finish with more elaborate colophons claiming that the king himself wrote, checked and deposited the tablet in the palace ana tāmartišu "for his (own) viewing" and similar phrases. ${ }^{55}$ For instance:

Tablet of Ashurbanipal, great king, strong king, king of the world, king of the land of Ashur, beloved of the great gods, to whom the gods Šamaš and Adad taught broad wisdom, who has learned and internalised divination, the secret of heaven and earth, the wisdom of Šamaš and Adad. He wrote, inspected, and checked this tablet and deposited it in his palace. ${ }^{56}$

Here, the "secret" is the practice of divination which Ashurbanipal is privy to, not the tablet himself: it is a claim about his learnedness, not a protective admonition about the tablet. Ashurbanipal had no need to invoke protective measures, for his collection was stored in the high-security environment of the royal palace where no theft was possible. ${ }^{57}$ More than that, at one level he seems not to have acknowledged the separate existence of the scholars around him who might have wanted access to his collection.

As this colophon shows, Ashurbanipal often presented himself as a copyist of scholarship. However, as the text itself - a chapter from the sacrificial divination series Bārûtu - is written in the same elegant, anonymous chancery hand of all Assyrian royal output, it is highly unlikely that Ashurbanipal physically wrote it or any of the scholarly tablets produced in his name once he was king.

53 Hunger, Babylonische und Assyrische Kolophone, nos. 328, 338, 339. For a more detailed discussion of Ashurbanipal's tablet collections, see Robson, Ancient Knowledge Networks, chapter 3. 54 É.GAL ${ }^{\mathrm{md}}$ aš-šur-DÙ-IBILA LUGAL ŠÚ LUGAL ${ }^{\mathrm{d}} \mathrm{aš-šur}{ }^{\mathrm{ki}}$ (Hunger, Babylonische und Assyrische Kolophone, no. 317).

55 E.g., Hunger, Babylonische und Assyrische Kolophone, nos. 318-19, 323-25.

56 țup-pu ${ }^{\mathrm{m}}$ AN.ŠÀR-DÙ-IBILA LUGAL GAL ${ }^{\text {ú }}$ LUGAL dan-nu LUGAL ŠÚ LUGAL KUR AN.ŠÀR ${ }^{\mathrm{ki}}$ | na-ram DINGIR.MEŠ GAL.MEŠ šá ${ }^{\mathrm{d} U T U}$ u ${ }^{\mathrm{d}}$ IŠKUR šá GEŠTU.MIN DAGAL-tu 4 ú-šá-hi-zu-šú-ma | NAM.AZU AD.HAL AN ${ }^{-e} u$ KI ${ }^{\text {tì }}$ né-me-qi ${ }^{\mathrm{d}}{ }^{\mathrm{d}}{ }^{\mathrm{d} U} \mathrm{u}$ u ${ }^{\mathrm{d}} \mathrm{IŠKUR}$ i-hu-zu-ma | uš-ta-bi-lu ka-ras-su țup-pu $\mathrm{UR}_{5}^{\text {-tú }}$ iš-țur is-niq ib-re-e-ma ina qé-reb É.GAL-šú ú-kin (Hunger, Babylonische und Assyrische Kolophone, no. 325).

57 On Assyrian palace security see Karen Radner, "Gatekeepers and Lock Masters: The Control of Access in Assyrian Palaces," in Your Praise is Sweet: A Memorial Volume for Jeremy Black from Students, Colleagues and Friends, ed. Heather D. Baker, Eleanor Robson, and Gábor Zólyomi (London: British Institute for the Study of Iraq, 2010), 269-80. 
Yet supposedly no-one else was involved in their production. Nor was anyone else meant to read them. Not a single one of Ashurbanipal's tablets carries a date of production, and not a single one bears any sort of protective formula or warning to future readers. These were the king's own tablets and no-one else at all was to share them.

Nor was anyone else to be attributed with prior knowledge. While several of Ashurbanipal's colophon types note that they have been copied from earlier sources, they never give the sort of precise information that we have seen was favoured by all scholarly groups we have looked at so far. Instead we find vague statements such as "according to the wording of original tablets (and writing-boards) from the land of Aššur and the land of Sumer and Akkad." 58 The whole of Assyria and Babylonia were at the king's intellectual disposal, in other words: no-one community or individual should be credited with particular knowledge, which now all belonged to the crown.

\subsection{Destruction Events as Survival Bottlenecks for Cuneiform Scholarship}

Ashurbanipal's singularly solipsistic view of himself as sole scholar was not intrinsically catastrophic for cuneiform scholarship outside the palace in Nineveh. So far as we can tell, the urban scholarly communities of Huzirina and Assur continued relatively unaffected by his actions: both the Nur-Šamaš and the Baba-šumu-ibni families continued to produce scholarly tablets, and therefore also to attract apprentices and clients, until the 610 s BCE..$^{59}$ It was only then that

58 Hunger, Babylonische und Assyrische Kolophone, nos. 318, 328, 336. Rykle Borger, "Bemerkungen zu den akkadischen Kolophonen," Welt des Orients 5 (1969-70): 165-71, at 168, notes just one exception: four tablets of the ritual purification ritual Bit Rimki were copied ki-i KA ${ }^{g i s ̌} l e-u_{5}$-um/giš ZU GABA.RI KÁ.DINGIR.RA ${ }^{\mathrm{ki}}$, "according to the wording of original writing-boards from Babylon." Perhaps in this case it was important to show that the ritual was steeped in genuine Babylonian tradition.

59 The latest dated tablet from the Huzirina cache is Gurney and Hulin, The Sultantepe Tablets, no. 300 (ed. Markham J. Geller, "Incipits and Rubrics," in Wisdom, Gods and Literature: Studies in Assyriology in Honour of W.G. Lambert, ed. Andrew R. George and Irving L. Finkel [Winona Lake: Eisenbrauns, 2000], 225-58), copied by a son of Nabu-zer-kitti-lešir of the Nur-Šamaš family, dated to the eponymate of Bel-ahhu-ușur, either 621 BCE (Julian E. Reade, "Assyrian Eponyms, Kings and Pretenders, 648-605," Orientalia 67 [1998]: 255-65) or 616 BCE (“Sequence of Post-canonical Eponyms," in The Prosopography of the Neo-Assyrian Empire, Volume 1/I: A, ed. Karen Radner [Helsinki: The Neo-Assyrian Text Corpus Project, 1998], xviii-xx). The Baba-šumu-ibni 
the full consequences of the king's actions, entwined with the devastating war he waged in Babylonia, were realised.

Because Ashurbanipal's grandiose project for erasing the geography of cuneiform scholarship was never completed, it has left clear evidence behind. First, there are the raw materials - other people's tablets - that were still present in the royal palaces at their destruction. Second, there is documentary evidence of the editorial process, which involved coercion as well as compliance. Third, as we shall see in the final section, Ashurbanipal's actions remained in Babylonian cultural memory for over half a millennium after his death and the fall of Assyria itself.

Even - or perhaps especially - the scholarly families closest to Ashurbanipal were subject to his acquisitive passions. We have already seen that 85 or so of the scholarly tablets written or owned by Gabbu-ilani-ereš men were found not in Nabu's temple in Kalhu but on the royal citadel in Nineveh - even though many of them explicitly say that they were written in Kalhu. Lieberman states that there is "no reason to assume that they were part of the king's library" but instead suggests that they remained in the family's possession, implying that they had a residence on the royal citadel (for which there is no archaeological evidence one way or another). ${ }^{60}$ However, he overlooks an important piece of evidence in the form of an inventory, now in three non-joining fragments, from the royal citadel in Nineveh. ${ }^{61}$ It originally comprised a six-column list of scholarly works that (formerly?) belonged to named individuals, including a man called Aplaya (who can be identified as a țupšar Enūma Anu Ellil from the Babylonian city of Borsippa ${ }^{62}$ and Esarhaddon's chief āšipu Adad-šumu-uṣur, whom we have already met above.

collection contains several works mentioning the name of king Sin-šarru-iškun (r. 623-612 BCE) (Maul, "Die Tontafelbibliothek," 204).

60 Stephen Lieberman, "Canonical and Official Cuneiform Texts: Towards an Understanding of Assurbanipal's Personal Tablet Collection," in Lingering over Words: Studies in Ancient Near Eastern Literature in Honor of William L. Moran, ed. Tzvi Abusch, John Huehnergard, and Piotr Steinkeller (Atlanta: Scholars Press, 1990), 305-36. At least one piece of a tablet excavated from the Kalhu Ezida in the 1950s joins another supposedly found in Nineveh by the Victorian explorers, however (Wiseman and Black, Literary Texts, 33 no. 229).

61 K 11922+ (Wilfred G. Lambert, "A Late Assyrian Catalogue of Literary and Scholarly Texts," in Kramer Anniversary Volume: Cuneiform Studies in Honor of Samuel Noah Kramer, ed. Barry L. Eichler, Jane W. Heimerdinger, and Åke W. Sjöberg [Kevelaer: Butzon \& Bercker; NeukirchenVluyn: Neukirchener, 1976], 313-18); online edition at http://oracc.org/cams/misc/P399525

62 He wrote at least 13 divinatory reports to king Esarhaddon in the 670s BC (Hermann Hunger, Astrological Reports to Assyrian Kings, State Archives of Assyria 8 [Helsinki: Helsinki University 
Adad-šumu-uṣur is named in the first surviving line of a piece that belonged to the bottom of the tablet. Scribal convention dictated that this name marked the end of the list of items relating to him. Because we cannot reconstruct the exact spatial relationship between the three fragments it may be that none of the compositions listed on the other two were his. But if we assume that Adad-šumu-ușur's tablets were listed immediately below Aplaya's then they included full sets of the celestial and terrestrial omen series Enūma Anu Ellil and Šumma Ālu, "including non-canonical tablets, word-commentaries and expositions"; five classic lexical lists; the dream omen series Zìqiqu and the cultic topography Tintir = Babylon; at least eight literary works including the Babylonian Epic of Creation Enūma Eliš and the epics of Gilgamesh and Etana; and presumably other works on now-missing pieces of the tablet.

This list fits well with Lieberman's characterisation of Adad-šumu-uṣur's father Nabu-zuqup-kena's tablets, written in Kalhu but found in Nineveh: mostly Enūma Anu Ellil, as well as commentaries on it and other works about the celestial bodies; Šumma Ālu and other omen collections; prayers and rituals; and Tablet XII of The Epic of Gilgamesh. ${ }^{63}$ Given the fragmentary nature of the inventory, and the fact that Nabu-zuqup-kena's ownership of tablets can only be ascertained by surviving colophons, this is an impressive overlap. Perhaps they entered the palace collection when Adad-šumu-uṣur died; perhaps he donated them himself.

Either way, such accession was part of a larger pattern of royal tablet acquisition, both voluntary and coerced, from within the king's inner circle and beyond. ${ }^{64}$ Most famously, huge numbers of scholarly tablets and writing boards arrived in Nineveh from Babylonia after Assurbanipal's defeat of a major insurrection there in 648 BCE, led by his brother Šamaš-šumu-ukin. Seven more inventories, just as fragmentary as the one just discussed, catalogue incoming compositions, grouped, as before, by prior owner and original location. ${ }^{65}$ About a seventh of the scholarly tablets found on the royal citadel are in Babylonian, as opposed to Assyrian handwriting, and most concern divination, Ashurbanipal's favourite

Press, 1992], nos. 356-68) and a letter to the queen mother (Parpola Letters from Assyrian and Babylonian Scholars, no. 154)

63 Lieberman, “A Mesopotamian Background,” 206-8.

64 Eleanor Robson, "The Clay Tablet Book in Sumer, Assyria and Babylonia," in A Companion to the History of the Book, ed. Simon Eliot and Jonathan Rose (Oxford: Blackwell, 2010), 67-83; eadem, Ancient Knowledge Networks, chapter 3.

65 F. Mario Fales and J. Nicholas Postgate, Imperial Administrative Records, Part I: Palace and Temple Administration, State Archives of Assyria 7 (Helsinki: Helsinki University Press, 1992), nos. 49-56; Simo Parpola, “Assyrian Library Records,” Journal of Near Eastern Studies 42 (1983): 1-29. 
subject. ${ }^{66}$ In this way, urban communities throughout northern Babylonia lost their writings to the king.

But, as we saw in the previous section, those origins, so carefully documented by palace administrators, had to be erased and local variation homogenised before they were fit for royal consumption. Akkullanu, šangû-priest of the god Aššur's temple in Assur, oversaw the production of scholarly tablets for a king, either Esarhaddon or Assurbanipal, and discussed editorial matters with him. ${ }^{67}$ Perhaps the originals that his team copied were from his temple, the most important in the land. A short report from immediately after the war documents local men overseeing captive Babylonians inside the Assyrian palaces, copying scholarly works or reproducing them from memory. For instance, a man named Banunu (who may be the āšipu from Kalhu discussed above), is said to be supervising the son of the city-governor of Nippur who "has completed the series (Enūma Anu Ellil) and has been put in irons". ${ }^{68}$ It was surely these men Akkullanu, Banunu and their charges - who transformed and homogenised the many local knowledge traditions, as represented by the incoming tablets, into a uniform, timeless, geographically neutral body of learning for the king.

Ashurbanipal's grandiose editorial scheme was never completed. The fouryear war against Babylonia had been vastly expensive and produced none of the usual haul of booty. Cuneiform scholarship may have had huge cultural value but it did not pay for the upkeep of the empire. Textual production petered out, the archives fell silent, the scholars disappeared from court in the course of the 640s BCE. ${ }^{69}$ Just a few decades later, terminally weakened by Ashurbanipal's rule, the Assyrian empire finally collapsed under the weight of another drive for Babylonian independence, this time fought with the aid of Median and other allies. Assur fell in 614 BCE, Nineveh and Kalhu in 612, while the Nur-Šamaš family probably

66 Jeanette C. Fincke, “The Babylonian Texts of Nineveh: Report on the British Museum's Ashurbanipal Library Project,” Archiv für Orientforschung 50 (2003/04): 111-49.

67 Parpola, Letters from Assyrian and Babylonian Scholars, nos. 101-3. Akkullanu's celestial omen reports for royal clients cover the period 676-650 BCE (Hunger, Astrological Reports, nos. 100-112; Parpola, Letters from Assyrian and Babylonian Scholars, nos. 84-108, 232; Stephen W. Cole and Piotr Machinist, Letters from Assyrian and Babylonian Priests to Kings Esarhaddon and Assurbanipal, State Archives of Assyria 13 [Helsinki: Helsinki University Press, 1998], no. 16).

68 The full passage reads: ${ }^{\mathrm{md}}$ MAŠŠŠU DUMU LÚ.GÚ.EN.NA | ÉŠ.GÀR ug-da-mir | si-par-ri AN.BAR šá-kin | ina É re-du-te | ina IGI ${ }^{\text {m} b a-a-n u-n i ~ p a-a q-q i d ~ \mid ~ d u l-l u ~ i n a ~ S ̌ U . M I N-s ̌ u ́ ~ l a-a ́ s ̌-s ̌ u ́ ~ " N i n u r-~}$ ta-gimilli, the son of the šandabakku, has completed the Series and has been put in irons. He is assigned to Banunu in the Succession Palace but there is no work for him at present" (Fales and Postgate, Imperial Administrative Records, Part II, no. 156 obv. 8-13).

69 See Robson, Ancient Knowledge Networks, chapters 2-3 for more details. 
abandoned their house in Huzirina when nearby Harran - now the last bastion of the empire - was besieged in 610 or 605 BCE.

The sacking of all of these cities and towns entailed the destruction, abandonment and eventual collapse of the buildings in which scholarly tablets were kept - from palaces and temples to family houses. All of the thousands of Assyrian tablets found in modernity by archaeologists were, de facto, tablets taken out of ancient circulation. What we can read today is precisely what was no longer accessible to read for later generations in antiquity. All that editorial work in the royal palace at Nineveh, which resulted in the recensions that modern Assyriology takes as the starting point for textual reconstruction, was in fact by and large an end point. The decade 614-605 BCE marks the definitive end of cuneiform culture in Assyria.

Of course we cannot know how many Assyrian scholars were amongst the survivors of this catastrophe. Very many must have died, as witnessed by the abandonment of the Nur-Šamaš home in Huzirina. ${ }^{70}$ Some were able to start anew in Babylonia and elsewhere, trading on memorised knowledge and rescued tablets to integrate into new communities. Some men and some tablets certainly made it as far south as Uruk in the marshlands of Babylonia, where, ironically, the insurrection against Assyria had originally fomented. ${ }^{71}$

Independent Babylonia flourished under rebel king Nabopolassar (r. 627-605 BCE) and his son Nebuchadnezzar II (r. 606-562 BCE). As in Assyria, and in earlier times of Babylonian self-rule, there were scholars at court, attached to temples as part-time prebendary priests, and working for private clients and patrons, in many combinations. ${ }^{72}$ Nevertheless, the sudden halving of cuneiform culture's sphere of circulation, on top of Ashurbanipal's earlier depredations, must have had a significantly deleterious effect that needed to be overcome. Quite apart from the loss of the Assyrian court and elites as a major source of patronage, there were fewer manuscripts in circulation and fewer scholarly practitioners to share (or compete) with.

Nevertheless, the sixth century BCE represents a period of prosperity and prestige for cuneiform scholarship, supported by the Babylonian dynasty's

70 Seton Lloyd and Nuri Gokçe, "Sultantepe: Anglo-Turkish Joint Excavations, 1952,” Anatolian Studies 3 (1953): 27-47.

71 Paul-Alain Beaulieu, "The Afterlife of Assyrian Scholarship in Hellenistic Babylonia," in Gazing on the Deep: Ancient Near Eastern and Other Studies in Honor of Tzvi Abusch, ed. Jeffrey Stackert, Barbara Nevling Porter, and David P. Wright (Bethesda: CDL Press, 2010), 1-18; Michael Jursa, “Die Söhne Kudurrus und die Herkunft der Neubabylonischen Dynastie," Revue d'Assyriologie 101 (2007): 125-36.

72 Robson, Ancient Knowledge Networks, chapter 4; Waerzeggers, “The Babylonian Priesthood.” 
patronage of temples and courtly advisors. It even survived the Cyrus the Great's conquest of Babylonia in 539 BCE. Even though the new Persian ruler was himself Zoroastrian he sought the active support of local temple communities to maintain social cohesion and economic success: essential prerequisites for a solid tax base. ${ }^{73}$ However, Babylonian uprisings against his successors Darius I and his son Xerxes I in 521 and 484 BCE led to devastating reprisals on the urban élites who had supported the rebels. ${ }^{74}$ Key temples in the cities of Sippar and Uruk were closed down forever, while others in Babylon, Borsippa and elsewhere were restaffed entirely with loyalists and their economic infrastructures reconfigured. Significant numbers of influential extended families disappear entirely from the cuneiform record at this point; or rather, $484 \mathrm{BCE}$ is the end date of many large personal and institutional tablet collections, whether archival or learned. Tens of thousands of scholarly tablets enter the archaeological record at this point - a second survival bottleneck for the written record, as well as for the communities that produced it, just a century and a half after the first. It represents a further halving of cuneiform scholarship's sphere of circulation, at least temporarily, another dramatic loss of patronage, institutional infrastructure, and wealthy client base.

Some northern Babylonian cities, such as Sippar, seem to have lost their tradition of cuneiform literacy forever, while others, such as Babylon and Borsippa, slowly re-established temple worship and associated scholarly activity. In southern cities like Nippur, which had remained loyal to Persian rule, life apparently continued entirely unchanged. In Uruk, southern power-base of the erstwhile Babylonian dynasty, the aftermath was more complicated. Families close to the old royal line, and thus perhaps sources of new claimants to the Babylonian throne if not active supporters of known rebels, disappear from the historical

73 Michael Jursa, "The Transition of Babylonia from the Neo-Babylonian Empire to Achaemenid Rule," in Regime Change in the Ancient Near East and Egypt: from Sargon of Agade to Saddam Hussein, ed. Harriet Crawford (Oxford: Oxford University Press, 2007), 73-94.

74 Caroline Waerzeggers, “The Babylonian Revolts against Xerxes and the 'End of Archives,"” Archiv für Orientforschung 50 (2003/04): 150-73; most recently Robson, "The Socio-economics of Cuneiform Scholarship." On the increasing financial pressures on temples at this period, which may have further exacerbated the situation, see Michael Jursa, "Money-based Exchange and Redistribution: The Transformation of the Institutional Economy in First-millennium Babylonia," in Autour de Polanyi: Vocabulaires, théories et modalités des échanges, ed. Philippe Clancier, Francis Joannès, Pierre Rouillard, and Aline Tenu (Paris: de Boccard, 2005), 171-86; idem, “Taxation and Service Obligations in Babylonia from Nebuchadnezzar to Darius and the Evidence for Darius' Tax Reform," in Herodot und das Persische Weltreich/Herodotus and the Persian Empire, ed. Robert Rollinger, Brigitte Truschnegg, and Reinhold Bichler (Wiesbaden: Harrassowitz, 2011), 431-48. 
record. Local elites were allowed to remain and slowly regrouped around a new temple, Reš, with a reformulated theology of the sky-god Anu, over the course of the fifth century BCE.

\subsection{Survival in a Time of Scarcity: Late Babylonian Cuneiform Scholarship}

This, then, is the devastating political background against which we should understand scholarly attitudes to sharing and protecting knowledge in the Uruk temple community with which this paper opens. ${ }^{75}$ As a bastion of rebellion against Assyria in the late seventh century BCE Uruk then became both a refuge for scholars (and others?) fleeing the north and a politically powerful centre of the new Babylonian regime. For nearly a decade from 627 BCE, for instance, crown prince Nebuchadnezzar had held a sinecure as šatammu-bishop of the Eanna temple. ${ }^{76}$ After the Achaemenid conquest, as discontent with the new imperial realities grew, Eanna was a focal point for increasing tensions between crown and cult. The temple was wound down early in Darius's reign, leading perhaps to some prominent elements of Uruk society supporting further rebellions on the accession of his son Xerxes. The young king certainly identified Uruk as a source of trouble, removing key families from city power - and perhaps removing them altogether - in 484 BCE.

The Ekur-zakir, Hunzu, Šangu-Ninurta and Sin-leqe-unninni families all survived these tumultuous decades in Uruk. When Alexander the Great marched into Babylon in 330 BCE, and then when his former general Seleucus eventually consolidated his own rule two decades later, it is no wonder that Uruk chose discretion over valour, obscurity over proximity to power. From late Achaemenid and into Seleucid times the city's ăšipus and kalûs knew very well that they could expect no royal patronage, for themselves or their temple. They were dependent entirely on income from part-time prebendary rights and from personal consultations for

75 Stevens, "Secrets in the Library"; Robson, "The Production and Dissemination"; eadem, "Tracing Networks of Cuneiform Scholarship"; "The Socio-economics of Cuneiform Scholarship"; Robson and Stevens, "Scholarly Tablet Collections in First-Millennium Assyria and Babylonia." For more detail on the differing fates of Babylonian scholarly communities, especially those of Borsippa and Uruk, post-484 BCE see Robson, "The Socio-economics of Cuneiform Scholarship," on which the following paragraphs are based, with extensive references to further literature.

76 Jursa, “Die Söhne Kudurrus,” 131. 
healing, horoscopes, and the like. ${ }^{77}$ But they could count on custom and respect from only a proportion of the urban community: Jews, Zoroastrians, Greeks, and other cultures were all part of city life now. It is impossible to tell whether or not Babylonian traditionalists still made up the majority of Uruk's population in the fourth and third centuries BCE but they certainly did not constitute the near-monopoly of earlier times.

In this light, then, the Uruk scholars' motivations for operating a "distributed library" of shared and protected knowledge must have been rather different to those of their Assyrian precursors, even if their strategies appear similar. As in the seventh-century urban scholarly communities examined above, the Uruk men acquired tablets from as far afield as Nippur, Kutha, and Der, as well as from others in their immediate communities. ${ }^{78}$ They borrowed and returned after "hasty excerpting," they worried about the risks of loaning works out themselves, and summoned their personal gods to protect them. In particular, we can understand better the particular protective measures that Stevens describes for compositions closest to individual scholars' livelihoods. ${ }^{79}$ Recall from the introduction the astronomical calculations drawn up in April 191 BCE, whose colophon utilises no less than four different protective strategies:

Tablet of Anu-belšunu, kalû of the god Anu, son of Nidintu-Anu, descendant of Sin-leqeunninni, Urukean. Hand of Anu-[aba-uter, his son, țupšar Enūma] Anu Ellil, Urukean.

Uruk, Nisannu (month I), year 1 21, Antiochus [was king].

He who reveres the gods Anu, Ellil and Ea [shall not take] it away by theft(?). Ephemeris, wisdom of Anu-ship, secret of the [great] gods, treasure of the scholars. The learned may show [the learned]; the unlearned may not [see. Taboo] of Anu, Ellil [and Ea, the great gods]. ${ }^{80}$

The āšipus and kalûs of Late Babylonian Uruk were responding to several types of threats through scarcity. The first was scarcity of royal patronage. That meant they could comfortably discount the possibility of large-scale confiscation of tablets à la Ashurbanipal, but the community memory of Xerxes's destruction of scholarly families, communities and temples must have remained raw. Less drastically but

77 Robson, “The Socio-economics of Cuneiform Scholarship,” 466.

78 Robson, "Tracing Networks of Cuneiform Scholarship,” 157.

79 Stevens, "Secrets in the Library."

80 pa-lih 2150 u 40 ina šur? qa? [la TÙM]-šú | a-ru-ú né-me-qi d 60 -ú-tú 'AD.HAL DINGIR?.[MEŠ

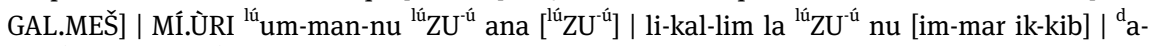
'nù ${ }^{\mathrm{d}}$ EN.LÍL 'ù? ['é-a DINGIR.MEŠ GAL.MEŠ] (Neugebauer, Astronomical Cuneiform Texts, no. $135 \mathrm{U}$ rev. 12-16; cf. Stevens, "Secrets in the Library," 252 no. 45). 
more immediately, the diversification of personal beliefs and religious practices meant that temple worshippers and clients for divination and healing were in ever shorter supply, while inheritance customs encouraged prebendary shares in temple income to be split into smaller and smaller parts. Meanwhile, the Assyrian and Achaemenid "survival bottlenecks" had taken untold numbers of scholarly works out of circulation, meaning that the textual basis of their professions was ever harder to come by.

Cynthia Jean has tracked the availability of compositions listed in the classic Āšipu's Handbook. ${ }^{81}$ In seventh-century Assur, where junior āšipu Kișir-Aššur of the Baba-šumu-ibni family made a copy of it, his family owned about half of the hundred or so compositions listed there (and maybe more if we take long-vanished writing-boards and unexcavated areas of the house into account). ${ }^{82}$ In late fifth-century Uruk junior āšipu Anu-ikșur of the Šangu-Ninurta family also made a copy, but his family had about half that number again. ${ }^{83}$ It must have been painfully obvious to him how many of the key works of his profession were no longer in circulation. In these straitened circumstances it was more important than ever before to hoard what one had, and to share only with a trusted few. Right until the last generation of scholarly activity in Uruk, in the mid-second century BCE, copyists were still writing on their tablets, "He who reveres the god Anu shall not carry it off." 84

Meanwhile, the story of cuneiform scholarship in the city of Babylon in the centuries after the anti-Achaemenid revolts is still to be pieced together. However, we do know that Xerxes saw Marduk's temple Esangila as the epicentre of the Babylonian independence movement, and that his reprisals included the decommissioning of its ziggurat, the dismantling of its prebendary system, and wholesale replacement of its senior personnel. There was some rapprochement with political power under Alexander the Great and the early Seleucids, when, for

81 Cynthia Jean, La magie néo-assyrienne en contexte: Recherches sur le métier d'exorciste et le concept d'āšipūtu (Helsinki: The Neo-Assyrian Text Corpus Project, 2006), 165-67.

82 KAR 44 (ed. Geller, "Incipits and Rubrics").

83 Ernst von Weiher, Spätbabylonische Texte aus Uruk, 5te Band, Ausgrabungen der Deutschen Forschungsgemeinschaft in Uruk-Warka, Endberichte 13 (Mainz: von Zabern, 1998), no. 321; Philippe Clancier, "Le manuel de l'exorciste d'Uruk," in Et il y eut un esprit dans l'Homme: Jean Bottéro et la Mésopotamie, ed. Xavier Faivre, Brigitte Lion, and Cécile Michel (Paris: De Boccard, 2009), 105-17.

84 pa-lih ${ }^{\mathrm{d}} 60$ là 'TÙM?-šú (Jan J. A. van Dijk and Werner R. Mayer, Texte aus dem Rēš-Heiligtum in Uruk-Warka [Berlin: Mann, 1980], no. 89 rev. 9), a list of historical kings and their scholarly advisor drawn up by Anu-belšunu's eponymous grandson in 165 BCE (Alan Lenzi, “The Uruk List of Kings and Sages and Late Mesopotamian Scholarship," Journal of Ancient Near Eastern Religions 8 [2008]: 137-69). 
instance, Esangila's šatammu-bishop Berossos (Babylonian Bel-re'ušu?) supposedly dedicated his famous Greek-language history Babyloniaca to Antiochus I in about 280 BCE. ${ }^{85}$ But this moment of cultural exchange is perhaps indicative of a larger sense that cuneiform scholarship was no longer viable as an independent body of knowledge, and needed to be shared more widely, in new languages. ${ }^{86}$ It is probably also in the third century BCE that some elements of Babylonian temple astronomy started to filter into the Greek tradition. ${ }^{87}$

The very last known cuneiform scholarly community functioned in Babylon over the period c. 150-50 BCE. Seleucid power and territory had been waning since the early second century BCE, under pressures from Rome to the west, Ptolemaic Egypt to the south, and the Parthians to the east. In 141 BCE, the royal city of Seleuceia-on-Tigris fell to the Parthians, who then set up a new imperial centre just $5 \mathrm{~km}$ away. Like the Seleucids before them, the new rulers of Babylonia rejected Babylon, some $65 \mathrm{~km}$ to the south, as a royal residence but allowed the city and its now much diminished temple, Esangila, to continue in existence.

Although we are lacking stratigraphically excavated, published archives from this period, informally recovered tablets from Victorian expeditions show that even at this late date Esangila was still a locus of scholarly as well as cultic activity. The famous Astronomical Diaries, the latest of which dates to $61 \mathrm{BCE},{ }^{88}$ were produced under its auspices, systematically recording a wealth of celestial and meteorological observational data, as well as increasingly frequent and extensive records of military, religious and political events. ${ }^{89}$ The Diaries regularly mention sacrifices and rituals in Esangila until at least $78 \mathrm{BCE},{ }^{90}$ while a small group of letters and legal documents of the temple scholars who made the

85 Johannes Haubold, Giovanni Lanfranchi, Robert Rollinger, and John Steele, The World of Berossos (Wiesbaden: Harrassowitz, 2013).

86 John Dillery, Clio's Other Sons: Berossus and Manetho (Ann Arbor: University of Michigan Press, 2015).

87 Alexander Jones, “Transmission of Babylonian Astronomy to Other Cultures," in Handbook of Archaeoastronomy and Ethnoastronomy, ed. Clive N. Ruggles (New York: Springer, 2015), 1877-81. 88 Abraham J. Sachs and Hermann Hunger, Astronomical Diaries and Related Texts from Babylonia, Volume III: Diaries from 164 B.C. to 61 B.C. (Vienna: Austrian Academy of Sciences, 1996), no. 62.

89 Reinhart Pirngruber, "The Historical Sections of the Astronomical Diaries in Context: Developments in a Late Babylonian Scientific Text Corpus,” Iraq 75 (2013): 197-210.

90 For instance, in May 78 BCE, "(the) governor of Babylon entered Babylon. That day, the šatammu-bishop of Esangila and the Babylonians, the kiništu-assembly of Esangila, provided [1 bull] and 2 (sheep) sacrifices at the Gate of the Prince's Son in Esangila as an offering for this governor of Babylon” (Sachs and Hunger, Astronomical Diaries, no. 77A obv. 26'-27'). 
Diary observations dates to 127-103 BCE. ${ }^{91}$ Most prominent amongst them was perhaps Itti-Marduk-balațu, son of Iddin-Bel, "gardener, city supervisor(?), overseer of the gods' temples, țupšar Enūma Anu Ellil, who had previously attended(?) Hyspaosines the king." 92 On 30 May, 127 BCE, the šatammu-bishop and temple assembly formally agreed that his two sons should take over his observational and calculational work. The latest surviving administrative records from Esangila were drawn up for a man called Rahim-Esu in 94-93 BCE, who essentially served as one of the temple's bankers: he managed its income and paid its salaries and expenses, running this operation as a profit-making business rather than as a direct employee..$^{93}$

Exactly contemporary with these records are scholarly texts written by members of three families associated with the temple, who also interrelated with each other: namely the descendants of Egibatila, Mušezib, and Nanna-utu. Babylonian scholarly lineages, along with Esangila's prebendary system of priestly duties and privileges, had largely been wiped out by Xerxes in 484 BCE $^{94}$; these families are amongst the few who survived or emerged in the aftermath. The Mušezib family had been central to the development of mathematical astronomy in the late fourth century BCE and continued to be members of the observational community in the late second, as witnessed by the letters and legal documents

91 Gilbert J. P. McEwan, Priest and Temple in Hellenistic Babylonia (Wiesbaden: Steiner, 1981), 17-21; Robartus J. van der Spek, "The Babylonian Temple during the Macedonian and Parthian Domination,” Bibliotheca Orientalis 42 (1985): 541-62, at 548-55; Michael Jursa, Neo-Babylonian Legal and Administrative Documents: Typology, Contents and Archives (Münster: Ugarit, 2005), 75; Johannes Hackl, "Materialien zur Urkundenlehre und Archivkunde der spätzeitlichen Texte aus Nordbabylonien” (PhD diss., Vienna University, 2013), 461-71.

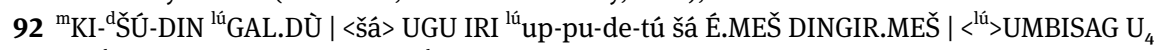
AN.NA ${ }^{\mathrm{d}}$ EN.LÍL.LÁ A «LÚ» šá ${ }^{\mathrm{m} M U}$ - ${ }^{\mathrm{d}}$ EN | ša i-na IGI-ma a-na Á as-pa-si-né-e LUGAL | DÙ (Theophilus G. Pinches, "A Babylonian Tablet Dated in the Reign of Aspasine," Babylonian and Oriental Record 4 [1896]: 131-35 obv. 9-13, cf. van der Spek, “The Babylonian Temple,” 549-551).

93 Gilbert J. P. McEwan, “Arsacid Temple Records,” Iraq 43 (1981): 131-43; Robartus J. van der Spek, "Cuneiform Documents on Parthian History: The Rahimesu Archive - Materials for the Standard of Living," in Das Partherreich und seine Zeugnisse/The Arsacid Empire: Sources and Documentation, ed. Josef Wiesehöfer (Stuttgart: Steiner, 1998), 205-58; Jursa, Neo-Babylonian Legal and Administrative Documents, 75-76; Johannes Hackl, "New Additions to the Rahimesu Archive: Parthian Texts from the British Museum and the World Museum Liverpool," in Silver, Money and Credit: A Tribute to Robartus J. van der Spek on the Occasion of his 65th Birthday, ed. Kristin Kleber and Reinhard Pirngruber (Leiden: Nederlands Instituut voor het Nabije Oosten, 2016), 87-106.

94 Hackl, "Materialien zur Urkundenlehre," 393. 
mentioned above. ${ }^{95}$ Some of their astronomical work survives, as well as a copy of Tablet X of The Epic of Gilgamesh, written for Itti-Marduk-balațu by one of his sons, Bel-ahhe-ușur. ${ }^{96}$ A few members of the Egibatila and Nanna-utu families also learned calculational astronomy, one of them studying with Bel-ahhe-uṣur's relative Marduk-šapik-zeri Mušezib. ${ }^{97}$ Meanwhile Nabu-balassu-iqbi, descendant of Egibatila, specialised in commentaries on various types of omen compilations. ${ }^{98}$ Three generations of kalu-lamenters from the Nanna-utu family, by contrast, wrote out long ritual laments "excerpted for singing” in Emesal, the ancient liturgical dialect of Sumerian, with interlinear Akkadian translations. ${ }^{99}$ One of them also trained a member of the Egibatila family in lamentation, which suggests that some of them too were kalûs. ${ }^{100}$

Nearly ninety scholarly tablets have so far been assigned to men of these three families, nearly half of which have (partially) surviving colophons dating to between 137 and 49 BCE. Apart from the fourteen tablets ana zamāri nashi

95 Joachim Oelsner, "Von Iqī̌sâ und einigen anderen spätgeborenen Babyloniern," in Studi su vicino Oriente antico dedicati alla memoria di Luigi Cagni, ed. Simonetta Graziani (Napoli: Istituto Universitario Orientale, 2000), 797-813, at 802-10; Eleanor Robson, Mathematics in Ancient Iraq: A Social History (Princeton: Princeton University Press, 2008), 221-26; Mathieu Ossendrijver, Babylonian Mathematical Astronomy: Procedure Texts (New York: Springer, 2012), 8 n. 44.

96 Parthian-period scholarly tablets with Mušezib colophons include Andrew R. George, The Babylonian Gilgameš Epic: Introduction, Critical Edition and Cuneiform Texts (Oxford: Oxford University Press, 2003), 114 source b (Gilgamesh); Grant Frame and Andrew R. George, "The Royal Libraries of Nineveh: New Evidence for King Ashurbanipal's Tablet Collecting," Iraq 67 (2004): 265-84, at 268 (literary letter); and Neugebauer, Astronomical Cuneiform Texts, no. 123Zk (astronomy).

97 Neugebauer, Astronomical Cuneiform Texts, nos. 18Zq, 122Zo, 420+821Zld, 611+822Zm.

98 The Cuneiform Commentaries Project, directed by Eckart Frahm at Yale University, gives a full catalogue, bibliography and online edition of Nabu-balassu-iqbi's commentaries (http://ccp.yale.edu/catalogue?ccp=\&scribe=Nabu-balassu-iqbi, accessed 1 September 2016).

99 George Reisner, Sumerische-Babylonische Hymnen nach Thontafeln Griechischer Zeit (Berlin: Spemann, 1896), nos. 3, 5, 10, 15, 18, 19, 20a, 25, 27, 28, 36, 44, 45, 46, 49, 51, 53, and 55; Ira Spar and Wilfred G. Lambert, eds., Literary and Scholastic Texts of the First Millennium BC, Cuneiform Texts in the Metropolitan Museum of Art 2 (New York: The Metropolitan Museum of Art, 2005), nos. 2, 8, and 15. Preliminary online edition by the Bilinguals in Late Mesopotamian Scholarship project directed by Steve Tinney at the University of Pennsylvania (http://oracc.org/blms, accessed 1 September 2016).

100 As I argue elsewhere, kalûs were often secondarily țupšar Enūma Anu Ellil, not only in Hellenistic Uruk where they are particularly well attested, but throughout the first millennium BCE in both Assyria and Babylonia; Eleanor Robson, "Who Wrote the Babylonian Astronomical Diaries?” in Keeping Watch in Babylon: from Evidence to Text in the Astronomical Diaries, ed. Johannes Haubold, John Steele, and Kathryn Stevens (Boston: Brill, forthcoming). 
"excerpted for singing," ${ }^{101}$ many more state explicitly that they have been copied from other sources - from one Belšunu's house, from the nearby city of Borsippa, even from magallatu (leather rolls) from Babylon. ${ }^{102}$ Ten have (partially) surviving protective formulae, across all four genres: astronomy, commentary, literature, and liturgy. Nabu-mušetiq-uddi Mušezib warns, "He who reveres the god Šamaš must not erase my handiwork." ${ }^{103}$ Nabu-balassu-iqbi Egibatila invokes the god Nabu, fully and inventively:

[He who reveres] the god Nabu should greatly, greatly guard and treasure (this tablet); [he may] not [show] it to anyone who is not the son of a work-master. ${ }^{104}$

It appears that the concept of the "learned" and the "unlearned" was now obsolete; it has been replaced with a social signifier. Although the exact meaning of the term mār bēl dulli, literally "son of a work-master," is unclear at this late period, it is perhaps related to the earlier mār banê, widely used into Hellenistic times. Liter-

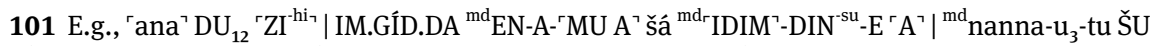
${ }^{\mathrm{md}}$ EN-MU-NA A ${ }^{\ulcorner} \mathrm{Šá}{ }^{\mathrm{m}} \mid{ }^{\mathrm{m}} \mathrm{KI}$ - ${ }^{\mathrm{d}} \mathrm{S} U$ U-TIN A ${ }^{\mathrm{m}} \mathrm{e}_{4}$-gi $\mathrm{i}_{7}$-ba-tìl-la ${ }^{\mathrm{T} T I N}$.TIR ${ }^{\mathrm{k}}\left[{ }^{\mathrm{k}}\right]$ "Extracted for singing. Exercise tablet of Bel-apal-iddin, son of Ea-balassu-iqbi, descendant of Nanna-utu. Handiwork of Bel-šumu-lišir, son of Itti-Marduk-balațu, descendant of Egibatila, Babylon” (Reisner, Sumerische-Babylonische Hymnen, no. 3 rev. 10'-13', a bilingual ballangu-liturgy).

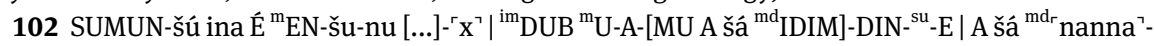
[ù-tu ...] "Its original is from the house of Belšunu [...]. Tablet of Bel-apla-[iddin, son of Ea]-balassu-iqbi, descendant of Nanna-[utu ...]" (Spar and Lambert, Literary and Scholastic Texts, no. 15, a bilingual šuillakku-prayer to the god Ninurta); 'LIBIR.RA-šú` TA muh-hi IM.GÍD.DA SUMUN GABA.RI bar-sìp ${ }^{\text {ki }}$ SAR-ma IGI.TAB | IM.GÍD.DA ${ }^{\mathrm{md}}$ NÀ-DIN ${ }^{\text {-su }}$-E A šá ${ }^{\mathrm{md}}$ AMAR.UTU-NUMUN-DÙ A ${ }^{\mathrm{md}}$ egi-ba-ti-la | ŠU.MIN ${ }^{\mathrm{md}}$ NÀ-MU-SI.SÁ DUMU-šú "Its original is from an old exercise tablet of Borsippa, copied and checked. Exercise tablet of Nabu-balassu-iqbi, son of Marduk-zer-ibni, descendant of Egibatila. Handiwork of Nabu-šum-lišir, his son” (Cyril. J. Gadd, Cuneiform Texts from Babylonian Tablets, \&c., in the British Museum, Part XLI [London: The British Museum, 1931] pl. 31 rev. 36-38; cf. pl. 32 rev. 24-26, both commentaries on the omen series Šumma Ālu); DUB

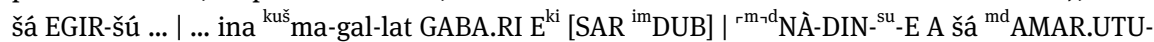
NUMUN-DÙ A ${ }^{\mathrm{md}} \mathrm{e}_{4}$-[gi $\mathrm{gi}_{7}$-ba-ti-la] "Tablet whose continuation (quotes the first line) is [written] on a leather roll, a manuscript from Babylon. [Tablet of] Nabu-balassu-iqbi, son of Marduk-zer-ibni, descendant of Egibatila” (Ernst Weidner, “Ein Kommentar zu den Schlangen-Omina," Archiv für Orientforschung 21 [1966]: 46, pl. 10 rev. 38-40, cf. http://ccp.yale.edu/P461205 rev. 5'-8', both commentaries on Šumma Ālu; http://ccp.yale.edu/P433502 rev. 1'-4', commentary on sacrificial omens, accessed 1 September 2016).

103 pa-lih 20 ŠU.MIN là í-pašx (GíN)-ršiț? (Frame and George, "The Royal Libraries of Nineveh," 368 rev. 23, a literary letter, on which see further below with note 108).

104 [GIM LIBIR-šú $\left.{ }^{\mathrm{md}} \mathrm{U}_{4} \cdot \mathrm{U}_{4}, \mathrm{U}_{4}\right] \cdot \cdot^{\mathrm{C}} \mathrm{U}_{4}{ }^{7} \cdot \mathrm{U}_{4} \cdot \mathrm{U}_{4} \cdot \mathrm{U}_{4} \cdot \mathrm{U}_{4} \cdot \mathrm{U}_{4}-\mathrm{DIN}^{\text {-su }}$-E A šá ${ }^{\mathrm{md}}$ AMAR.UTU-NUMUN-DÙ <A>

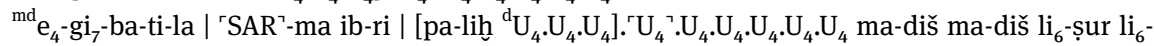
šá-qir al-la DUMU EN du-ul-la 'là’ [ú-kal-lam] (Spar and Lambert, Literary and Scholastic Texts, no. 69 rev. 3'-5', commentary on a medical text). 
ally translated as "son of the good," this phrase is explained by Michael Jursa as a "non-serf head of a household (loosely) affiliated to the temple." 105 The word dullu, "work," was a common term for the (now obsolete) labour-taxation paid by temple communities until the early Achaemenid period. ${ }^{106}$ If this identification of mār bēl dulli is correct, then the permissible sphere of circulation for scholarly writings has shifted from the highly cuneiform-literate to the temple community: a tacit acknowledgement that cuneiform was no longer meaningful in the world beyond ${ }^{107}$

Whatever this phrase might signify, unlike their Assyrian and Late Babylonian forebears, neither man articulates what the consequent divine punishment might be. Moreover most scholars in their circle write an even more perfunctory abbreviation of this standard phrase, omitting the offending action itself. "He who reveres the gods Šamaš and Marduk," declare the Egibatila and Nanna-utu men; "He who reveres the gods Bel and Beltiya," invoke the Mušezibs. ${ }^{108}$ Just what, exactly, the reverent man is supposed to do with the tablet - return, protect, treasure, not remove, not lose - and under what penalty, is never declared.

These phrases, as well as the explicitly stated copying habits described above, make it clear that the scholars of Parthian Babylon expected others to have access to their writings. Yet the lacklustre nature of their protective formulae suggests that they did not anticipate much inappropriate human interest in their writings, and/or did not really count on the gods to provide appropriate protection. Indeed, they seem to have given up on the protective habit entirely by the first century BCE. ${ }^{109}$ Certainly, at this very late juncture in Babylonian culture, there must have

105 Michael Jursa, "Labor in Babylonia in the First Millennium BC," in Labor in the Ancient World, ed. Piotr Steinkeller and Michael Hudson (Dresden: ISLET, 2015), 345-96, at 351.

106 Jursa, “Taxation and Service Obligations,” 442; idem, “Labor in Babylonia,” 352.

107 Independently Johannes Hackl, "Language Death and Dying Reconsidered: The Role of Late Babylonian as a Vernacular Language,” Imperium and Officium Working Papers, 2011. Vienna: http://iowp.univie.ac.at/, 16 posits the second century BCE - exactly the period we are discussing here - as the point at which Akkadian probably died out as a vernacular language in favour of Aramaic.

108 E.g., 'pa?-lih ${ }^{\mathrm{d}} \mathrm{UTU}$ u ${ }^{\mathrm{d}}$ AMAR.UTU (http://ccp.yale.edu/P461205 rev 9', see note above); palih ${ }^{\mathrm{d}}$ EN u ${ }^{\mathrm{d}} \mathrm{GAŠAN}$-ia (George, The Babylonian Gilgameš Epic, 114 source b rev. ii 18', see above with note 96). The following, damaged sign that George, The Babylonian Gilgameš Epic, 114 reads as GUR, the logogram for târu "to return," is to my mind more likely to be 'E` $\left[{ }^{\mathrm{ki}}\right]$ "Babylon" (cf. e.g., Spar and Lambert, Literary and Scholastic Texts, no. 2 rev. 20').

109 The latest dated tablet known to me that bears the phrase "He who reveres the gods Šamaš and Marduk" is DT 35, a commentary on the ominous calendar Iqqur Ipuš, written by a member of the Egibatila family in 103 BCE (http://ccp.yale.edu/P461300). At least eight tablets written by scholars in the Egibatila circle post-date it, the latest being a calculated table of full moons from 49 BCE by a member of the Nanna-utu family (Neugebauer, Astronomical Cuneiform Texts, no. 18Zq). 
been very few other cuneiform literate communities around. But if they were merely going through the motions, for custom's sake, why bother at all?

Fascinatingly, this group of scholars were still acutely aware of Ashurbanipal's long-ago plundering of the scholarship of northern Babylonia, as witnessed by two literary letters copied by members of the Mušezib and Egibatila families. ${ }^{110}$ One letter purports to be from "the obedient citizens of Borsippa," promising to obey the king's command to "Write out all the scribal learning in the property of the god Nabu and send it to me!" and referring him to Esangila for one particular text - a Sumerian vocabulary - that is not in their possession. ${ }^{111}$ The other letter is a longer response to a similar royal request for "all the scribal [learning, as much as there is, that is in the possession] of the great lord Marduk, my lord." In this composition, twelve named scholars from Babylon offer to write down all that is "stored in their minds like goods piled in a magazine" in exchange for silver and political favour. ${ }^{112}$

The historicity of the original letters is still hotly debated, but what matters here is that in Babylon, over half a millennium later, the group memory of this event was still current. However, in this late recounting, no original tablets left Babylonia for Nineveh (though we have seen in the previous section that this was not the case) and no scholars were chained up in the royal palace and forced to work. Instead they offered to transfer their knowledge from memory onto writing boards in return for royal respect and reward. This rose-tinted retelling was a

110 Frame and George, “The Royal Libraries of Nineveh”; cf. Eckart Frahm, “On Some Recently Published Late Babylonian Copies of Royal Letters," Nouvelles Assyriologiques Brèves et Utilitaires 43 (2005): 43-46.

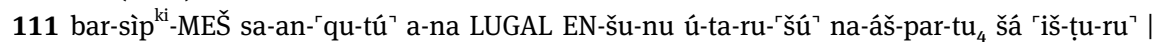

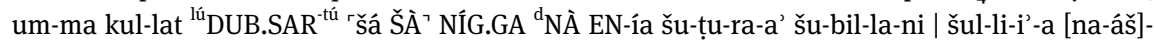
par- ${ }^{\top} \mathrm{tu}_{4}{ }^{\urcorner}$"The obedient citizens of Borsippa will return (i.e., fulfill) to their king the commission that he wrote, as follows: 'Write out all the scribal learning in the property of the god Nabu, my lord, and send it to me! Fulfill the commission!” (Frame and George, "The Royal Libraries of Nineveh,” 268 obv. 8-10). The colophon reads: GIM <SUMUN>-šú SAR-ma IGI.TAB u IGI.KÁR ${ }^{i m}$ DUB $^{\mathrm{md}}{ }^{\mathrm{EN}}$-TIN ${ }^{\text {su }}$ A šá ${ }^{\mathrm{md}}$ NÀ-DIB-U ${ }_{4}$.DA A ${ }^{\mathrm{m}}$ mu-še-zib | ŠU.MIN ${ }^{\mathrm{md}}$ NÀ-DIB-U ${ }_{4} \cdot$ DA A-šú “Copied and checked according to its <original>. Tablet of Bel-uballissu, son of Nabu-mušetiq-uddi, descendant of Mušezib. Handiwork of Nabu-mušetiq-uddi, his son” (rev. 22-23, and see note 103 above for its continuation).

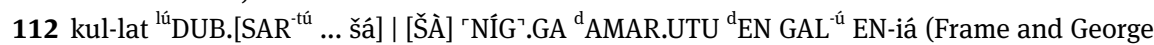

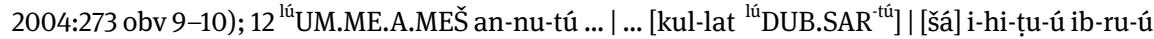
GIM gu-ru-'un'-né-e a-na kar-ši-šú-nu kam-su "these 12 scholars ... [all of scribal learning] that they have read and checked, stored in their minds like goods piled in a magazine” (obv. 13-14). The remains of the colophon are restored by Frahm, "On Some Recently Published Late Babylonian Copies,” 45) to read: [IM.GÍD.DA ${ }^{\mathrm{md}}$ EN-MU-SI.SÁ DUMU šá ${ }^{\mathrm{m}} \mathrm{KI}-{ }^{\mathrm{d}}$ AMAR.UTU]-DIN DUMU ${ }^{\mathrm{md}} \mathrm{e}_{4}$-gi $\mathrm{gi}_{7}$-ba- ${ }^{-} \mathrm{ti}^{\urcorner}$-[la ...] "[Exercise tablet of Bel-šum-lišir, son of Itti-Marduk]-balațu, descendant of Egibatila [...]". 
reimagining of a time in which cuneiform scholarship was still in high demand, when even the world's most powerful king treated the learned with the deference they felt they deserved but had lost long ago.

\subsection{Conclusions}

The costs and benefits to sharing or concealing written knowledge in cuneiform culture were weighted differently in different times and places, according to the opportunities and pressures of the moment. Most simply put, the higher up the social scale the less need there was for scholarly reciprocity. Members of the NurŠamaš and Baba-šumu-ibni family circles in seventh-century Huzirina and Assur took care to acknowledge their sources and copyists (who mostly had junior status), and to return tablets borrowed from others. In turn they expected the same courtesies from others in their intellectual communities. Without such a formally encoded etiquette for sharing and protecting, any one individual's chances of access to the written word were substantially diminished. By contrast their courtier contemporaries, the descendants of Gabbu-ilani-ereš and their colleagues, did not credit their scribes and did not expect tablets to be borrowed or copied by others. Stored in the inner courtyard of Ezida on the royal citadel, under the watchful eye of Nabu himself, their writings were as safe as could possibly be. Only the king himself could assert any claim on them. And this was part of a much larger, longerterm royal attempt to centralise and monopolise scholarly knowledge. Focusing overwhelmingly on divination, ritual, healing, and prayer, Ashurbanipal's vast personal tablet collection aimed not only to diminish other humans' access to learning but to maximise his own ability to predict and control the gods' will.

However, even if - or rather, precisely because - in reality sharing and protecting of written knowledge was socially asymmetrical, it was not possible to admit that truth in practice. Hence the euphemistic worries expressed about "the unlearned" gaining inappropriate access to writings which, as we saw at the very start of this article, would be have been utterly incomprehensible to all but a handful of the highly cuneiform literate. We have also seen how tightly individual families held on to scholarly roles across the generations, whether as royal advisors like the Gabbu-ilani-ereš men, or temple ritualists like the Sin-leqe-unninnis. There was no real threat of untrained outsiders accessing sufficient professional instruction, never mind sufficient social status, to set themselves up as rival āšipus or kalûs to the long-established urban dynasties.

Rather, as we have seen, scholarly communities were most at risk from statelevel threats because cuneiform scholarship was seen to be powerful, and there- 
fore highly politicised and threatening. For Ashurbanipal in the mid-seventh century BCE, the means to read and understand the gods' will should be the king's above all, and even if he did not intend to deprive others entirely of those means, he insisted on unprecedentedly complete access to the writings that enabled communication with the divine. War against his brother Šamaš-šumuukin in Babylonia gave him the perfect opportunity to pursue that plan but also, ultimately, led to its and the empire's collapse, gravely imperilling the survival of cuneiform scholarship in the process. Conversely, 150 years later, Darius and Xerxes were not believers in the Babylonian gods but saw the temples as a source of taxation revenue on the one hand and of political rebellion on the other. Shutting down the latter while maintaining the former entailed the removal of local centres of resistance, both institutional and familial. The scholars and temples of northern Babylonia were again grievously affected. Over the course of a century and a half, cuneiform scholarship's sphere of circulation had halved and halved again.

The scholarly community, ever resilient, rebuilt and reconfigured itself once more. But henceforth it would be wary of too much engagement with royal power, which could veer from the over-invested to the violently hostile. From the fifth century onwards, in the absence of kingly patronage, cuneiform scholarship's real struggle was to find local validation and income, whether through temple affiliation or private clientele. But urban populations now had more choice of divine authority than ever before, and traditional Babylonian learning had to compete with new ways of thinking from both east and west. Worries about protecting and sharing written knowledge were perhaps most acute in the late Achaemenid and early Seleucid periods. But eventually, over the course of the third and second centuries BCE, the shrinking community of the cuneiform-literate accepted that they had lost the battle for status and influence amongst their fellow city dwellers. One strategy was to share their learning more widely, in alphabetic scripts, via mechanisms and to readerships that we still do not fully understand. But on the street and in the (emptying) temple there was now little interest in what these erstwhile experts did and thought, compared to the glory days of cuneiform culture, few fellow-travellers with whom to share it and therefore very little need to protect their traditional writings in the once customary way.

\section{References}

Paul-Alain Beaulieu, “The Afterlife of Assyrian Scholarship in Hellenistic Babylonia," in Gazing on the Deep: Ancient Near Eastern and Other Studies in Honor of Tzvi Abusch, ed. Jeffrey Stackert, Barbara Nevling Porter, and David P. Wright (Bethesda: CDL Press, 2010), 1-18. 
Carl Bezold, Catalogue of the Cuneiform Tablets in the Kouyunjik Collection of the British Museum, Volume 5 (London: The British Museum, 1899).

Rykle Borger, "Bemerkungen zu den akkadischen Kolophonen," Welt des Orients 5 (1969-70): 165-71.

Philippe Clancier, “Le manuel de l'exorciste d'Uruk," in Et il y eut un esprit dans l'Homme: Jean Bottéro et la Mésopotamie, ed. Xavier Faivre, Brigitte Lion, and Cécile Michel (Paris: De Boccard, 2009), 105-17.

Stephen W. Cole and Piotr Machinist, Letters from Assyrian and Babylonian Priests to Kings Esarhaddon and Assurbanipal, State Archives of Assyria 13 (Helsinki: Helsinki University Press, 1998).

Manfred Dietrich, The Neo-Babylonian Correspondence of Sargon and Sennacherib, State Archives of Assyria 17 (Helsinki: Helsinki University Press, 2003).

Jan J. A. van Dijk and Werner R. Mayer, Texte aus dem Rēš-Heiligtum in Uruk-Warka (Berlin: Mann, 1980).

John Dillery, Clio's Other Sons: Berossus and Manetho (Ann Arbor: University of Michigan Press, 2015).

F. Mario Fales and J. Nicholas Postgate, Imperial Administrative Records, Part I: Palace and Temple Administration, State Archives of Assyria 7 (Helsinki: Helsinki University Press, 1992).

F. Mario Fales and J. Nicholas Postgate, Imperial Administrative Records, Part II: Provincial and Military Administration, State Archives of Assyria 11 (Helsinki: Helsinki University Press, 1995).

Jeanette C. Fincke, “The Babylonian Texts of Nineveh: Report on the British Museum's Ashurbanipal Library Project," Archiv für Orientforschung 50 (2003/04): 111-49.

Eckart Frahm, “Nabu-zuqup-kenu, das Gilgameš-Epos und der Tod Sargons II," Journal of Cuneiform Studies 51 (1999): 73-90.

Eckart Frahm, "On Some Recently Published Late Babylonian Copies of Royal Letters," Nouvelles Assyriologiques Brèves et Utilitaires 43 (2005): 43-46.

Eckart Frahm, "Keeping Company with Men of Learning: The King as Scholar," in The Oxford Handbook of Cuneiform Culture, ed. Karen Radner and Eleanor Robson (Oxford: Oxford University Press, 2011), 508-33.

Grant Frame, Rulers of Babylonia: From the Second Dynasty of Isin to the End of Assyrian Domination (1157-612 BC), Royal Inscriptions of Mesopotamia: Babylonian Periods 2 (Toronto: University of Toronto Press, 1995).

Grant Frame and Andrew R. George, “The Royal Libraries of Nineveh: New Evidence for King Ashurbanipal's Tablet Collecting," Iraq 67 (2004): 265-84.

Cyril. J. Gadd, Cuneiform Texts from Babylonian Tablets, \&c., in the British Museum, Part XLI (London: The British Museum, 1931).

Markham J. Geller, "Fragments of Magic, Medicine and Mythology from Nimrud," Bulletin of the School of Oriental and African Studies 63 (2000): 331-39.

Markham J. Geller, "Incipits and Rubrics," in Wisdom, Gods and Literature: Studies in Assyriology in Honour of W.G. Lambert, ed. Andrew R. George and Irving L. Finkel (Winona Lake: Eisenbrauns, 2000), 225-58.

Markham J. Geller, “Look to the Stars: Babylonian Medicine, Magic, Astrology and Melothesia," Max Planck Institute for the History of Science Preprints 401 (Berlin: Max Planck Institute for the History of Science, 2010).

Andrew R. George, The Babylonian Gilgameš Epic: Introduction, Critical Edition and Cuneiform Texts (Oxford: Oxford University Press, 2003). 
Petra D. Gesche, Schulunterricht in Babylonien im ersten Jahrtausend v. Chr., Alter Orient und Altes Testament 275 (Münster: Ugarit, 2000).

Oliver R. Gurney and Jacob J. Finkelstein, The Sultantepe Tablets, Volume I (London: British Institute of Archaeology at Ankara, 1957).

Oliver R. Gurney and Peter Hulin, The Sultantepe Tablets, Volume II (London: British Institute of Archaeology at Ankara, 1964).

Johannes Hackl, “Language Death and Dying Reconsidered: The Role of Late Babylonian as a Vernacular Language," Imperium and Officium Working Papers, 2011. Vienna: http://iowp. univie.ac.at/.

Johannes Hackl, “Materialien zur Urkundenlehre und Archivkunde der spätzeitlichen Texte aus Nordbabylonien” (PhD diss., Vienna University, 2013).

Johannes Hackl, "New Additions to the Rahimesu Archive: Parthian Texts from the British Museum and the World Museum Liverpool," in Silver, Money and Credit: A Tribute to Robartus J. van der Spek on the Occasion of his 65th Birthday, ed. Kristin Kleber and Reinhard Pirngruber (Leiden: Nederlands Instituut voor het Nabije Oosten, 2016), 87-106. Johannes Haubold, Giovanni Lanfranchi, Robert Rollinger, and John Steele, The World of Berossos (Wiesbaden: Harrassowitz, 2013).

Hermann Hunger, Babylonische und Assyrische Kolophone (Kevelaer: Butzon \& Bercker; Neukirchen-Vluyn: Neukirchener, 1968).

Hermann Hunger, Astrological Reports to Assyrian Kings, State Archives of Assyria 8 (Helsinki: Helsinki University Press, 1992).

Cynthia Jean, La magie néo-assyrienne en contexte: Recherches sur le métier d'exorciste et le concept d'āšipūtu (Helsinki: The Neo-Assyrian Text Corpus Project, 2006).

Alexander Jones, "Transmission of Babylonian Astronomy to Other Cultures," in Handbook of Archaeoastronomy and Ethnoastronomy, ed. Clive N. Ruggles (New York: Springer, 2015), 1877-81.

Michael Jursa, Neo-Babylonian Legal and Administrative Documents: Typology, Contents and Archives (Münster: Ugarit, 2005).

Michael Jursa, "Money-based Exchange and Redistribution: The Transformation of the Institutional Economy in First-millennium Babylonia," in Autour de Polanyi: Vocabulaires, théories et modalités des échanges, ed. Philippe Clancier, Francis Joannès, Pierre Rouillard, and Aline Tenu (Paris: de Boccard, 2005), 171-86.

Michael Jursa, “Die Söhne Kudurrus und die Herkunft der Neubabylonischen Dynastie," Revue d'Assyriologie 101 (2007): 125-36.

Michael Jursa, "The Transition of Babylonia from the Neo-Babylonian Empire to Achaemenid Rule," in Regime Change in the Ancient Near East and Egypt: from Sargon of Agade to Saddam Hussein, ed. Harriet Crawford (Oxford: Oxford University Press, 2007), 73-94.

Michael Jursa, "Taxation and Service Obligations in Babylonia from Nebuchadnezzar to Darius and the Evidence for Darius' Tax Reform," in Herodot und das Persische Weltreich/ Herodotus and the Persian Empire, ed. Robert Rollinger, Brigitte Truschnegg, and Reinhold Bichler (Wiesbaden: Harrassowitz, 2011), 431-48.

Michael Jursa, "Labor in Babylonia in the First Millennium BC," in Labor in the Ancient World, ed. Piotr Steinkeller and Michael Hudson (Dresden: ISLET, 2015), 345-96.

Wilfred G. Lambert, "A Late Assyrian Catalogue of Literary and Scholarly Texts," in Kramer Anniversary Volume: Cuneiform Studies in Honor of Samuel Noah Kramer, ed. Barry L. Eichler, Jane W. Heimerdinger, and Åke W. Sjöberg (Kevelaer: Butzon \& Bercker; Neukirchen-Vluyn: Neukirchener, 1976), 313-18. 
Wilfred G. Lambert, Babylonian Oracle Questions (Winona Lake: Eisenbrauns, 2007).

Alan Lenzi, Secrecy and the Gods: Secret Knowledge in Ancient Mesopotamia and Biblical Israel (Helsinki: The Neo-Assyrian Text Corpus Project, 2008).

Alan Lenzi, "The Uruk List of Kings and Sages and Late Mesopotamian Scholarship," Journal of Ancient Near Eastern Religions 8 (2008): 137-69.

Stephen Lieberman, “A Mesopotamian Background for the So-called Aggadic 'Measures' of Biblical Hermeneutics?” Hebrew Union College Annual 58 (1987): 157-225.

Stephen Lieberman, "Canonical and Official Cuneiform Texts: Towards an Understanding of Assurbanipal's Personal Tablet Collection," in Lingering over Words: Studies in Ancient Near Eastern Literature in Honor of William L. Moran, ed. Tzvi Abusch, John Huehnergard, and Piotr Steinkeller (Atlanta: Scholars Press, 1990), 305-36.

Alasdair Livingstone, Mystical and Mythological Explanatory Works of Assyrian and Babylonian Scholars (Oxford: Clarendon, 1986).

Alasdair Livingstone, "On the Organized Release of Doves to Secure Compliance of a Higher Authority," in Wisdom, Gods and Literature: Studies in Assyriology in Honour of W.G. Lambert, ed. Andrew R. George and Irving L. Finkel (Winona Lake: Eisenbrauns, 2000), 375-88.

Alasdair Livingstone, “Ashurbanipal: Literate or Not?” Zeitschrift für Assyriologie 97 (2007): 98-118.

Seton Lloyd and Nuri Gokçe, "Sultantepe: Anglo-Turkish Joint Excavations, 1952," Anatolian Studies 3 (1953): 27-47.

Stefan M. Maul, Zukunftsbewältigung: Eine Untersuchung altorientalischen Denkens anhand der babylonisch-assyrischen Löserituale (Namburbi) (Mainz: von Zabern, 1994).

Stefan M. Maul, “Die Tontafelbibliothek aus dem sogenannten »Haus des Beschwörungspriesters, «" Assur-Forschungen: Arbeiten aus der Forschungsstelle »Edition Literarische Keilschrifttexte aus Assur « der Heidelberger Akademie der Wissenschaften, ed. Stefan M. Maul and Nils P. Heeßel (Wiesbaden: Harrassowitz, 2010), 189-228.

Gilbert J. P. McEwan, “Arsacid Temple Records,” Iraq 43 (1981): 131-43.

Gilbert J. P. McEwan, Priest and Temple in Hellenistic Babylonia (Wiesbaden: Steiner, 1981).

Otto Neugebauer, Astronomical Cuneiform Texts, Volumes I-III (Berlin: Springer, 1955).

Joachim Oelsner, "Von Iqī̌sâ und einigen anderen spätgeborenen Babyloniern," in Studi su vicino Oriente antico dedicati alla memoria di Luigi Cagni, ed. Simonetta Graziani (Napoli: Istituto Universitario Orientale, 2000), 797-813.

Mathieu Ossendrijver, Babylonian Mathematical Astronomy: Procedure Texts (New York: Springer, 2012).

Simo Parpola, “Assyrian Library Records," Journal of Near Eastern Studies 42 (1983): 1-29.

Simo Parpola, Letters from Assyrian Scholars to the Kings Esarhaddon and Assurbanipal, Part II: Commentary and Appendices (Kevelaer: Butzon \& Bercker, 1983; repr., Winona Lake: Eisenbrauns, 2007).

Simo Parpola, Letters from Assyrian and Babylonian Scholars, State Archives of Assyria 10 (Helsinki: Helsinki University Press, 1993).

Simo Parpola, "Sequence of Post-canonical Eponyms," in The Prosopography of the Neo-Assyrian Empire, Volume 1/I: A, ed. Karen Radner (Helsinki: The Neo-Assyrian Text Corpus Project, 1998), xviii-xx.

Theophilus G. Pinches, "A Babylonian Tablet Dated in the Reign of Aspasine," Babylonian and Oriental Record 4 (1896): 131-35.

Reinhart Pirngruber, "The Historical Sections of the Astronomical Diaries in Context: Developments in a Late Babylonian Scientific Text Corpus," Iraq 75 (2013): 197-210. 
Karen Radner, "Gatekeepers and Lock Masters: The Control of Access in Assyrian Palaces," in Your Praise is Sweet: A Memorial Volume for Jeremy Black from Students, Colleagues and Friends, ed. Heather D. Baker, Eleanor Robson, and Gábor Zólyomi (London: British Institute for the Study of Iraq, 2010), 269-80.

Julian E. Reade, “Assyrian Eponyms, Kings and Pretenders, 648-605,” Orientalia 67 (1998): 255-65.

Julian E. Reade, “Ninive (Nineveh)," in Reallexikon der Assyriologie und Vorderasiatischen Archäologie, Vol. 9, ed. Dietz O. Edzard (Berlin: De Gruyter, 2001), 388-433.

George Reisner, Sumerische-Babylonische Hymnen nach Thontafeln Griechischer Zeit (Berlin: Spemann, 1896).

Eleanor Robson, Mathematics in Ancient Iraq: A Social History (Princeton: Princeton University Press, 2008).

Eleanor Robson, "The Clay Tablet Book in Sumer, Assyria and Babylonia," in A Companion to the History of the Book, ed. Simon Eliot and Jonathan Rose (Oxford: Blackwell, 2010), 67-83.

Eleanor Robson, “Empirical Scholarship in the Neo-Assyrian Court," in The Empirical Dimension of Ancient Near Eastern Studies, ed. Gebhardt Selz and Klaus Wagensonner (Vienna: LIT, 2011), 603-30.

Eleanor Robson, "The Production and Dissemination of Scholarly Knowledge," in The Oxford Handbook of Cuneiform Culture, ed. Karen Radner and Eleanor Robson (Oxford: Oxford University Press, 2011), 557-76.

Eleanor Robson, "Reading the Libraries of Assyria and Babylonia," in Ancient Libraries, ed. Jason König, Katerina Oikonomopoulos, and Greg Woolf (Cambridge: Cambridge University Press, 2013), 38-56.

Eleanor Robson, "Tracing Networks of Cuneiform Scholarship with Oracc, GKAB and Google Earth," in Archaeologies of Text: Archaeology, Technology and Ethics, ed. Matthew Rutz and Morag Kersel (Oxford: Oxbow Books, 2014), 142-63.

Eleanor Robson, "The Socio-economics of Cuneiform Scholarship after the 'End of Archives': Views from Borsippa and Uruk," in At the Dawn of History: Ancient Near Eastern Studies in Honour of J. N. Postgate, ed. Yagmur Heffron, Adam Stone, and Martin Worthington (Winona Lake: Eisenbrauns, 2017), 455-70.

Eleanor Robson, Ancient Knowledge Networks: A Social Geography of Cuneiform Scholarship in the First Millennium BC (forthcoming).

Eleanor Robson, “Who Wrote the Babylonian Astronomical Diaries?” in Keeping Watch in Babylon: from Evidence to Text in the Astronomical Diaries, ed. Johannes Haubold, John Steele, and Kathryn Stevens (Boston: Brill, forthcoming).

Eleanor Robson and Greta Van Buylaere, “Assyrian-Babylonian Scholarly Literacies” (unpublished manuscript).

Eleanor Robson and Kathryn Stevens, "Scholarly Tablet Collections in First-Millennium Assyria and Babylonia," in The Earliest Libraries: Library Tradition in the Ancient Near East, ed. Gojko Barjamovic and Kim Ryholt (Oxford: Oxford University Press, forthcoming).

Abraham J. Sachs and Hermann Hunger, Astronomical Diaries and Related Texts from Babylonia, Volume III: Diaries from 164 B.C. to 61 B.C. (Vienna: Austrian Academy of Sciences, 1996).

Daisuke Shibata, "A Nimrud Manuscript of the Fourth Tablet of the Series Mīs pî, CTN IV 170(+)188, and a Kiutu Incantation to the Sun God," Iraq 70 (2008): 189-203.

Ira Spar and Wilfred G. Lambert, eds., Literary and Scholastic Texts of the First Millennium BC, Cuneiform Texts in the Metropolitan Museum of Art 2 (New York: The Metropolitan Museum of Art, 2005). 
Robartus J. van der Spek, "The Babylonian Temple during the Macedonian and Parthian Domination," Bibliotheca Orientalis 42 (1985): 541-62.

Robartus J. van der Spek, "The Astronomical Diaries as a Source for Achaemenid and Seleucid History," Bibliotheca Orientalis 50 (1993): 91-101.

Robartus J. van der Spek, "Cuneiform Documents on Parthian History: The Rahimesu Archive Materials for the Standard of Living," in Das Partherreich und seine Zeugnisse/The Arsacid Empire: Sources and Documentation, ed. Josef Wiesehöfer (Stuttgart: Steiner, 1998), 205-58.

Kathryn Stevens, "Secrets in the Library: Protected Knowledge and Professional Identity in Late Babylonian Uruk," Iraq 75 (2013): 211-53.

Greta Van Buylaere, “A Palaeographic Analysis of Neo-Assyrian” (PhD diss., University of Udine, 2009).

Niek Veldhuis, "Levels of Literacy," in The Oxford Handbook of Cuneiform Culture, ed. Karen Radner and Eleanor Robson (Oxford: Oxford University Press, 2011), 68-89.

Pierre Villard, “L'education d’Assurbanipal,” Ktema 22 (1997): 135-49.

Caroline Waerzeggers, "The Babylonian Revolts against Xerxes and the 'End of Archives,"” Archiv für Orientforschung 50 (2003/04): 150-73.

Caroline Waerzeggers, "The Babylonian Priesthood in the Long Sixth Century BC," Bulletin of the Institute of Classical Studies 54 (2011): 59-70.

Ernst Weidner, “Ein Kommentar zu den Schlangen-Omina," Archiv für Orientforschung 21 (1966): 46.

Ernst von Weiher, Spätbabylonische Texte aus Uruk, 5te Band, Ausgrabungen der Deutschen Forschungsgemeinschaft in Uruk-Warka, Endberichte 13 (Mainz: von Zabern, 1998).

Donald J. Wiseman, “Assyrian Writing Boards," Iraq 17 (1955): 3-13.

Donald J. Wiseman and Jeremy A. Black, Literary Texts from the Temple of Nabû, Cuneiform Texts from Nimrud 4 (London: British School of Archaeology in Iraq, 1996). 